\title{
Heyelanlı Bir Alanın Yeniden Etkinleşme Potansiyelinin İncelenmesi: Harmandalı-İzmir Katı Atık Düzenli Depolama Alanı Örneği
}

\author{
Investigation of the Reactivation Potential of a Landslide Area: a case study of Harmandall- \\ Izmir waste disposal site
}

\author{
Cem KINCAL ${ }^{1} \mathbb{D}$, Tümay KADAKCİ KOCA ${ }^{2} \mathbb{D}$, Mehmet Yalçın KOCA ${ }^{1} \mathbb{D}$ \\ ${ }^{1}$ Dokuz Eylül Üniversitesi, Mühendislik Fakültesi, Jeoloji Mühendisliği Bölümü, Buca/İzmir \\ ${ }^{2}$ Muğla Sttkı Koçman Üniversitesi, Mühendislik Fakültesi, Jeoloji Mühendisliği Bölümü, Menteşe, Muğla
}

Geliş (Received): 30 Nisan (April) 2021, Düzeltme (Revised): 08 Haziran (June) 2021, Kabul (Accepted): 15 Haziran (June) 2021

\section{ÖZ}

Bu çalışmanın amacı, İzmir-Çiğli semtinde yer alan Harmandalı Düzenli Katı Atık Depolama Sahası'nın KB'ya bakan yamacında 18 Şubat 2013 tarihinde meydana gelmiş heyelanın oluşum nedenlerini ve aynı kayma dairesi üzerinde hareketin tekrar etme potansiyelini araştırmaktır. Eylül-2016'da yeniden başlayan jeolojik ve jeoteknik çalışmalar ışığında bu potansiyelin varlığı değerlendirilmiştir. Başlangıç heyelanı sonrasında, kayma hareketinin yavaşlayarak devam ettiği, heyelan sonrasında açılan inklinometre kuyularında gerçekleştirilen okumalarla belirlenmiştir. 2010 yılında katı atık (çöp) şevlerinin önüne koruma yapısı olarak bir sedde inşa edilmiştir. Sedde tabanında yer alan yüksek plastisiteli kil bandından geçen kayma dairesi boyunca, KB'ya doğru yatay yönde 64.5 mm'lik bir yer değiştirme hareketi meydana gelmiştir. Bu hareket, idari binaların duvarlarında çatlamalar, ana bağlantı yolunda bozulmalar ve seddede sıkışmanın etkisini gösteren kabarma şeklinde deformasyonlara neden olmuştur. Mart-2013 ve Eylül-2016'da presiyometre deneyleri ve inklinometre kuyularında yapılan okumaların sonucu olarak, heyelanın boyuna kesiti, kayma mekanizması ortaya çıkartılmıştır. Buna ek olarak, kaymaya neden olan andezitik tüf ayrışma ürünü yüksek plastisiteli killerin mühendislik özellikleri araştırılmıştır.

Anahtar Kelimeler: Heyelan, İnklinometre, Katı Atık, Oturma, Presiyometre, Yüksek Plastisiteli Kil

\section{ABSTRACT}

The aim of this study is to investigate the causes of the landslide occurred on 18 February 2013 at the NWfacing slope of the Harmandal waste disposal site located in İmir-Çiğli and the reactivation potential of the same circular slip surface. In the light of the geological and geotechnical studies resumed in September-2016; the reactivation potential has been evaluated. An embankment (a barrier) was built as a protection structure in front of the slopes of solid waste in 2010. It was determined from the readings in the inclinometer boreholes drilled right after the landslide that the sliding slowed down gradually after the initial landslide. A $64.5 \mathrm{~mm}$ displacement occurred in horizontal direction towards $N W$ along the circular slip surface passing through the high plasticity clay band located under the embankment. This movement caused cracks on the walls of the administration buildings, disruption of the main connection road, and deformation such as buckling indicating the effect of compression within the embankment. The longitudinal cross-section showing the sliding mechanism has been prepared based on the pressuremeter tests and the readings taken from the inclinometer boreholes drilled at different locations in 
Kıncal, Kadakci Koca, Koca

March-2013 and September-2016. In addition, the engineering properties of high plasticity clays (CH), which are the weathering products of the andesitic tuffs that cause sliding, have been investigated.

Keywords: Landslide, Inclinometer, Solid Waste, Settlement, Pressuremeter, High Plasticity Clay

\section{GíRiș}

Katı atık depolama sahası İzmir Körfezi'nin kuzeyinde, İzmir İli Menemen İlçesi sınırları içindeki Harmandalı mevkiinde yer almaktadır. İzmir şehir merkezine uzaklığı yaklaşık $30 \mathrm{~km}$ ' dir. Aralık-1990 tarihinde Hacettepe Üniversitesi Uluslararası Karst Su Kaynakları Uygulama ve Araştırma Merkezi tarafindan inceleme alanı etüd edilmiş, "İzmir-Harmandalı Çöp Depolama Alanı Zemin Araştırmaları Raporu" hazırlanmıştır (Günay vd., 1990). 1992 yılından günümüze değin günde yaklaşık 5000 ton, yılda 1.8 milyon ton evsel, endüstriyel ve tıbbi atık $1.2 \mathrm{~km}^{2}$ lik alanda düzenli olarak depolanmaktadır (Şekil 1). 18 Şubat 2013 'te yoğun yağışlar sonrasında, katı atık şevinin batıya bakan yamacından itibaren başlayan, seddeyi kapsayan ve en batıda ofis binalarına kadar uzanan bir alanda kayma hareketi meydana gelmiştir (Şekil 1 ve 2). Kayma özellikle ana nakliye yolu üzerinde önemli deformasyonlara neden olmuştur (Şekil 3). $\mathrm{Bu}$ çalışmanın amacı, kaymayı oluşturan etmenleri ve kayma dairesinin konumunu hem 2013 hem de 2016 yıllarında yapılmış jeolojik ve jeoteknik çalışmalara dayanan verilerle araştırmak, kaymanın nedenlerini ve mekanizmasını incelemektir. 2016 yılının başlangıcından itibaren, seddenin doğusunda yer alan katı atık şevlerinde hareketlenme izleri ve yer değiştirmeler gibi yüzeyde meydana gelen öncekilere ek yeni deformasyonlar gözlenmiştir. Böylece, aynı kayma dairesi boyunca hareketin tekrar edebileceği kuşkusu oluşmuştur. Bu nedenle, 2016'da yeniden jeolojik ve jeoteknik çalışmalar başlatılmıştır. Kayma dairesi üzerine konumlandırılmış inklinometre kuyularında
Eylül-2016'da tüm yıl boyunca yapılan okumalar, aynı kuyularda gerçekleştirilen presiyometre deneyleriyle heyelanın yeniden aktive olup olamayacağ 1 belirlenmiştir.

18 Şubat 2013'te kayma meydana geldikten 48 gün sonra üç adet inklinometre kuyusu hazırlanmış ve ilk okumalar 8 Nisan 2013 tarihinde yapılabilmiştir. İnklinometre kuyularının derinlikleri SK-1'de 35 m, SK-2'de $32 \mathrm{~m}$ ve $\mathrm{SK}-3$ 'de ise $45 \mathrm{~m}$ 'dir. Bu kuyular, sahada ilk açılan inklinometre kuyularıdır (Şekil 1). Diğer taraftan, Eylül-2016'da, heyelan sahasında derinlikleri $25 \mathrm{~m}$ ile $65 \mathrm{~m}$ arasında değişen 10 adet yeni sondaj kuyusu açılmış ve bunların konumları da Şekil 1'de gösterilmiştir. Sondaj kuyularının derinlikleri, yeraltı suyu derinlikleri, kuyu ağız kotları, presiyometre deney sayıları ve kuyu boyunca yüksek plastik kil seviyesi geçilen yerlerin derinlikleri (zayıflık zonları) ise Çizelge 1'de toplu olarak verilmiştir. Eylül-2016'da, önceden hareket etmiş kütlenin kayma yönünde (K30B-G30D ekseni üzerinde) bir hat boyunca üç adet (İK-1, İK-2 ve İK-3 inklinometre kuyusu), seddenin GB'de yer alan katı atık depolama alanına kadar kayma zonunun uzanıp uzanmadığını kontrol etmek için de aynı hat üzerinde İK-8 inklinometre kuyusu açılmıştır (Şekil 1). Önceden 3, daha sonra da 4 adet olmak üzere toplam yedi adet inklinometre kuyusuna ait okuma sonuçları bu çalışmada değerlendirilmiştir. Heyelan sonrası, Mart2013'te açılmış üç adet inklinometre kuyusunda (SK-1, SK-2 ve SK-3) ölçülmüş deplasmanların miktarı ve derinlikleri heyelanın kayma dairesinin yerinin ve konumunun belirlenmesinde dikkate alınmıştır. 


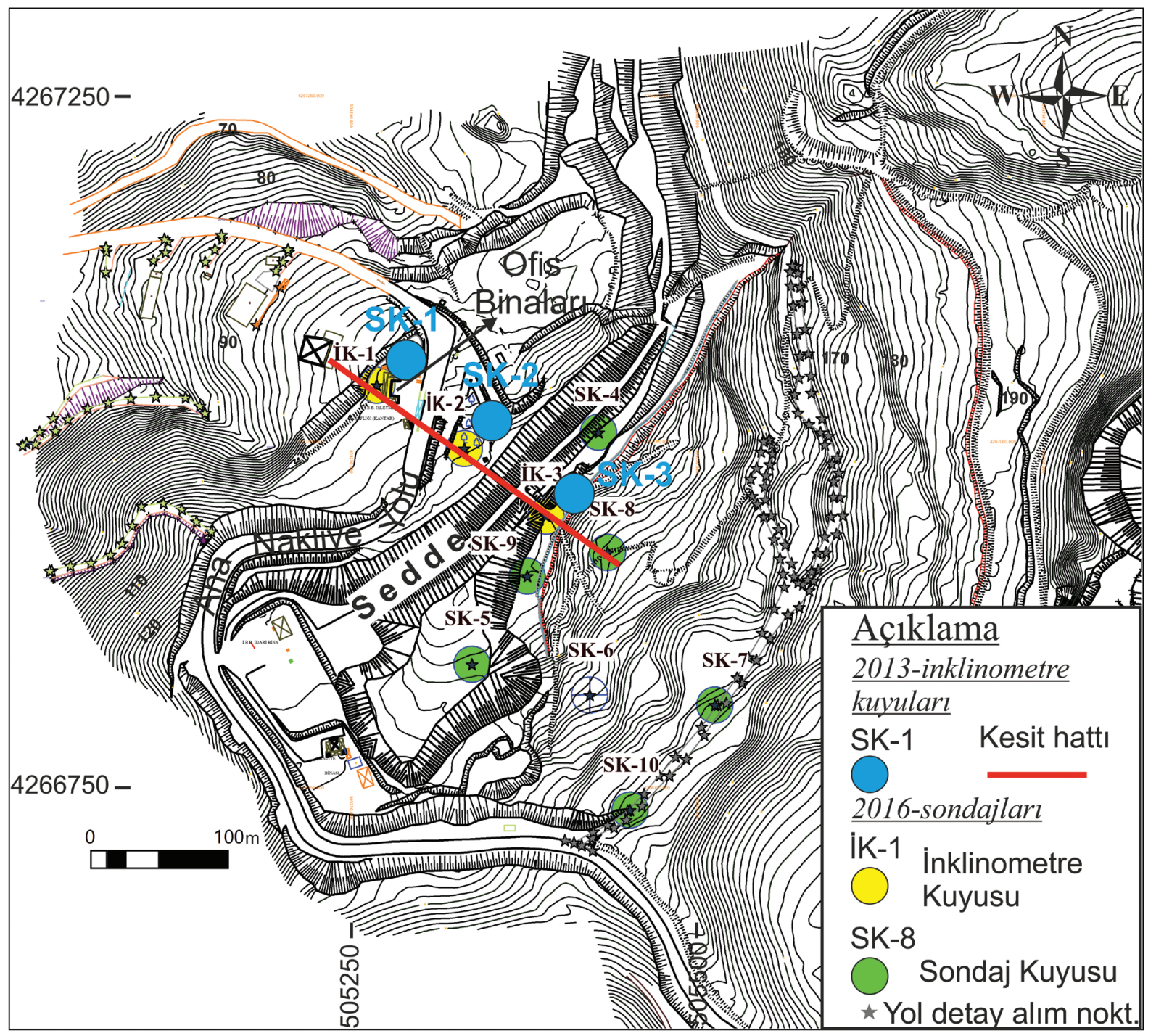

Şekil 1. Sedde, ofis binaları, ana nakliye yolu, katı atık düzenli depolama alanının KB'ya bakan şevleri, 2013 ve 2016 yıllarında açılmış sondajların lokasyonları.

Figure 1. The embankment, office buildings, main transport road, $N W$ facing slopes of the solid waste disposal site and locations of the boreholes drilled in 2013 and 2016.

2016'da yapılan çalıșmalarla da (inklinometre okumaları ve presiyometre deneyleri) kayma hareketinin devam edip etmediği belirlenmiş ve söz konusu kayma dairesi üzerinde, kayma hareketinin tekrar etme potansiyeli değerlendirilmiştir. Buna ek olarak, sedde altında yer alan ve içinden kayma düzleminin geçtiği yüksek plastisiteli killerin mühendislik özellikleri ve Şubat-2013 heyelanının kayma mekanizması üzerine olan etkileri ayrıntılı olarak incelenmiştir. $\mathrm{Bu}$ çalışma, heyelana yönelik yapılan şev stabilitesi çalışmalarını kapsamamaktadır. 


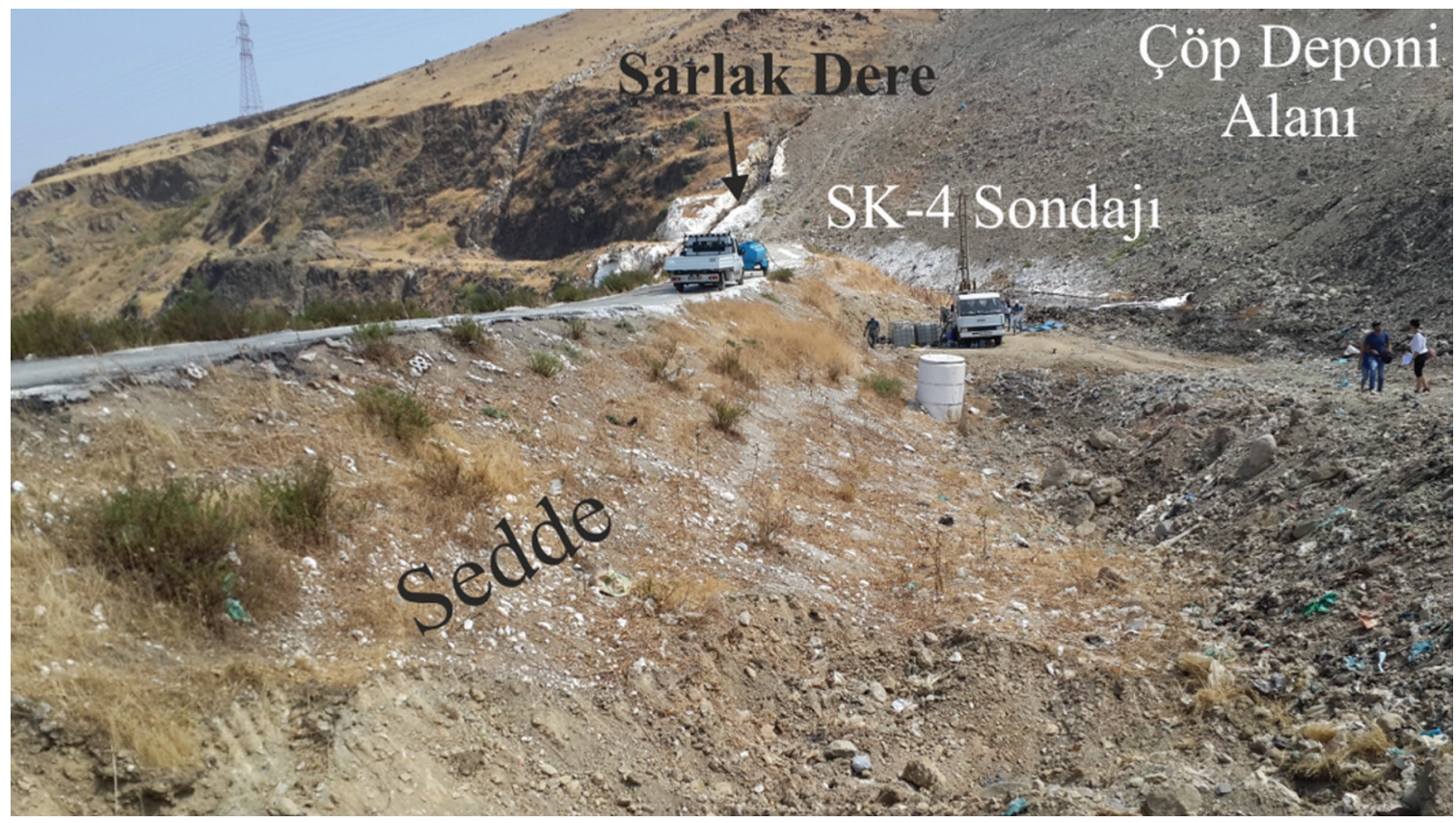

Şekil 2. Seddeyle katı atık depolama sahası arasında kalan hendekte açılmış SK-4 sondaj kuyusu.

Figure 2. SK-4 borehole drilled in the ditch area between the embankment and the solid waste disposal site.

Çizelge 1. Sondaj kuyularının derinlikleri, kuyularda ölçülen yeraltı suyu derinlikleri, kuyu ağzı kotları, presiyometre deney sayıları ile kuyularda yüksek plastisiteli kil seviyesi geçilen zonların derinlikleri (zayıflık zonları).

Table 1. Depth of boreholes and groundwater levels in the boreholes, elevations of borehole head, number of pressuremeter tests and the depths of the high plasticity clay zones (weakness zones).

\begin{tabular}{|c|c|c|c|c|c|c|c|}
\hline Konum & $\begin{array}{l}\text { Sondaj } \\
\text { No }\end{array}$ & Derinlik (m) & Kot (m) & $\begin{array}{c}\text { Dolgu+katı atık } \\
\text { kalınlığı }(\mathrm{m})\end{array}$ & $\begin{array}{c}\text { Yeraltı su } \\
\text { seviyesi }(\mathrm{m})\end{array}$ & $\begin{array}{c}\text { Presiyometre } \\
\text { deney sayis1 }\end{array}$ & $\begin{array}{c}\text { CH-tipi killerin } \\
\text { derinliği }(\mathrm{m})\end{array}$ \\
\hline \multirow{5}{*}{$\begin{array}{l}\text { Seddenin } \\
\text { batısında }\end{array}$} & İK-1 & 30 & 106.5 & 3.00 & 5.30 & 15 & $21-30 \mathrm{~m}$ \\
\hline & İK-2 & 40 & 111.7 & 0.30 & 6.80 & 20 & $19-23.5 \mathrm{~m}$ \\
\hline & İK-3 & 50 & 126.0 & 9.00 & 5.30 & 25 & $17-21.0 \mathrm{~m}$ \\
\hline & SK-4 & 50 & 120.5 & 20.0 & 1.40 & 12 & $13.3-17 \mathrm{~m}$ \\
\hline & SK-5 & 50 & 120.0 & - & 2.00 & 12 & - \\
\hline \multirow{5}{*}{$\begin{array}{c}\text { Seddenin } \\
\text { doğusunda }\end{array}$} & SK-6 & 60 & 146.0 & 17.6 & 16.8 & 12 & - \\
\hline & SK-7 & 54 & 160.0 & 42.5 & 39.0 & 12 & - \\
\hline & İK-8 & 65 & 137.0 & 20.6 & 17.8 & 25 & - \\
\hline & SK-9 & 38 & 127.0 & 20.0 & 20.0 & 0 & - \\
\hline & SK-10 & 25 & 164.0 & 15.0 & 14.5 & 6 & - \\
\hline & Toplam D & inlik: $462 \mathrm{~m}$ & & & & Toplam: 139 & \\
\hline
\end{tabular}

İK: İnklinometre kuyuları 


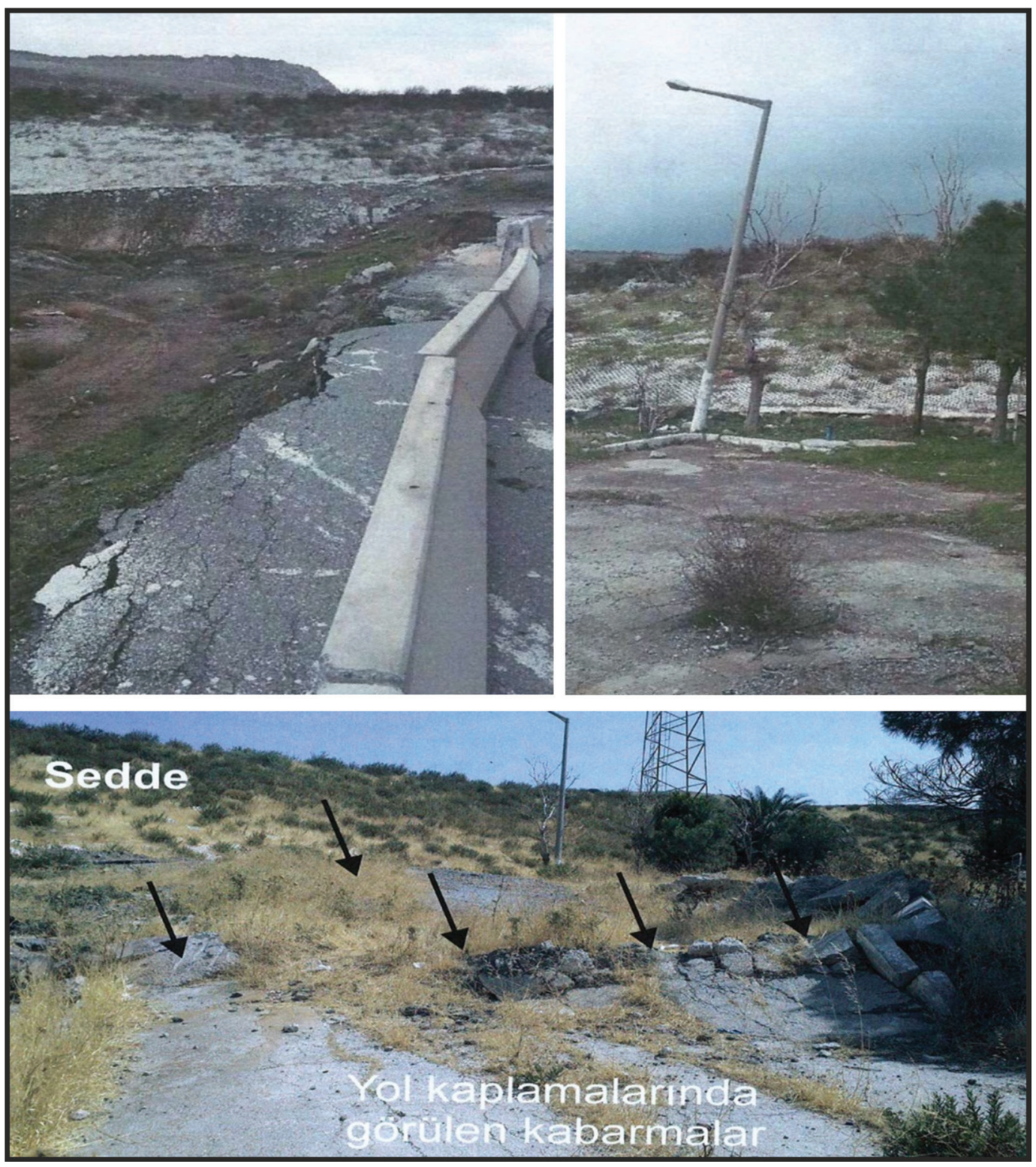

Şekil 3. Yol kenarındaki beton korumalıklarda meydana gelen yer değiştirmeler, asfalt yolda kabarmalar ve aydınlatma direğinde düşeyden sapma şeklinde gelişen deformasyonlar.

Figure 3. Displacements on the roadside concrete shelters, heavings in asphalt and deformation on concrete lighting pole as deviation from vertical.

\section{YÖNTEMLER}

İnklinometre ölçümleri ve presiyometre deneyleri kuyu içinde yapılan yerinde deneylerdir. Yüzey altında yanal yöndeki deformasyonları ölçmek için gerekli hazırlık yapıldıktan sonra inklinometre ölçümleri yapılır (Mikkelsen, 1996). İnklinometre cihazı, dijital bir inklinometre sondası, makaralı sonda kablosu ve veri iletimini sağlayan verici ile kuyu 
içerisine tespit edilen inklinometre borularından ibarettir (ASTM D6230-13, 2013). İnklinometre sondası özel muhafazası içinde okuma yapmak için kuyu içine sarkıtılır. $\mathrm{Bu}$ çalışmada, 2013 ve 2016 yıllarında sirasıyla 3 ve 4 adet inklinometre kuyusu açılmış ve bu kuyularda okumalar yapılmıştır (DEÜ, 2016). 2013 yılında yapılan okumalarla kayma dairesinin konumu şekillenmiş, 2016 yılında açılmış inklinometre kuyularında yapılan deformasyon ölçümleriyle de kayma dairesi üzerinde hareketin tekrar etme potansiyeli değerlendirilmiştir.

Presiyometre deneyi bir kuyu yükleme deneyidir ve uygulanan basınca karşı zeminde oluşan hacimsel deformasyon değerlerinin belirlenmesi ilkesine dayanır (ASTM D471900, 2000). Zeminlerden zayıf kayaçlara kadar değişen litolojik seviyelerde deney uygulanabilir. $\mathrm{Bu}$ çalışmada presiyometre deneylerinin yapılmasının amacı, inklinometre kuyularının düşey zemin profilleri boyunca kayma hareketlerine hassasiyet gösterebilecek veya önceden meydana gelen hareket nedeniyle örselenmiş ve zayıf bir zon olarak ortaya çıkmış zemin kesitlerinin derinliklerini belirlemektir. Eylül-2016'da açılmış İK-1, İK-2, İK-3 ve IKK-8 inklinometre kuyularında sirasıyla 15, 20, 25 ve 25 adet olmak üzere 85 adet, tüm kuyularla birlikte toplamda 139 adet presiyometre deneyi yapilarak deformasyon modülü $\left(\mathrm{E}_{\mathrm{M}}\right)$ ve presiyometre limit basinç $\left(\mathrm{P}_{\mathrm{L}}\right)$ değerleri ölçülmüştür (Çizelge 1).

Seddenin kendi ağırlığı nedeniyle zemine statik yüklerin etkimesi, kil bandında gerçekleşen konsolidasyonun başlica nedenidir. Suya doygun zeminlerde sıkışma esas olarak boşluklardan suyun dışarı çıkması sonucu meydana gelir (ASTM D2435-04, 2013). İnce taneli zeminlerin geçirgenliği çok düşük olduğundan, yüklenen zeminden suyun dışarı çıkması zamana bağlı olarak gelişmektedir. Bu çalışmada sedde altında yer alan plastik kil bandından örselenmemiş kil örnekleri alınarak üzerinde konsolidasyon deneyleri yapılmıştır. Konsolidasyon deneyi sonucunda, boşluk oranına karşılık logaritma basınç $(\mathrm{e}-\log \mathrm{P})$ eğrileri elde edilmiş ve bu eğriler üzerinde ön konsolidasyon basınçları $\left(\sigma_{c}^{\prime}\right)$ bulunmuştur (DEÜ, 2016). Buna göre, aşır1 konsolidasyon oranı (AKO) belirlenmiştir.

$\mathrm{AKO}=\frac{\sigma_{c}^{\prime}}{\sigma_{0}^{\prime}}$

Burada, $\sigma_{o}^{\prime}$; kil bandının orta noktasındaki efektif gerilmedir. AKO oran1, incelenen kilin normal (NC), aşırı (OC) veya henüz konsolidasyonunu tamamlanmamış (UC) olması hakkında bilgi verir. Buna ek olarak, sıkışma indisi $\left(c_{c}\right)$ konsolidasyon eğrisinden hesaplanmıştır.

$\mathrm{c}_{\mathrm{c}}=\frac{\Delta e}{\Delta \log P}$

Kil bandının kalınlığı $\left(\mathrm{H}_{\mathrm{o}}\right)$, sıkışma indisi $\left(c_{c}\right)$, seddenin ağırlığı nedeniyle meydana gelen gerilme $\operatorname{artışı}(\Delta e)$ ve kil bandının ortasındaki efektif gerilme değeri yardımıyla sedde tabanında yer alan kil bandının konsolidasyon oturması $\left(\mathrm{S}_{\mathrm{t}}\right)$ hesaplanmıştır.

$\mathrm{S}_{\mathrm{t}}=\frac{C_{c}}{1+e_{0}} H_{0} \log \left[\frac{\sigma_{0+\Delta \sigma}^{\prime}}{\sigma_{o}^{\prime}}\right]$

İK-1, İK-2 ve İK-3 konumundaki inklinometre kuyularında, sondajın kil bandını kestiği noktalardan örselenmemiş kil örnekleri alınmış ve bu örnekler üzerinde konsolidasyonludrenajlı (CD) kesme deneyleri yapılmıştır. Zeminlerin uzun süredeki kayma dirençlerinin belirlenmesi için drenajlı deneyler yapılmalıdır. Zeminin kayma direncini belirlemek için farklı normal yükler altında $(12,24$ ve $48 \mathrm{~kg})$ numuneler deneye tabi tutulmuştur. Kesme kutusu deneyleri ASTM (2004) standardına göre yapılmıştır. Deney, numuneyi kesme cihazına yerleştirip üzerine önceden belirlenmiş normal 
bir gerilme uygulamakla başlar. Deney sırasında aşırı boşluk suyu basınçları oluşmayacak şekilde numuneler yavaşça yüklenmiş ve sonunda drenajlı koşullar oluşturulmuştur. Deformasyon göstergeleri numunenin kalınlığını 0.0025 mm, yatay deplasmanı ise $0.025 \mathrm{~mm}$ hassasiyetle ölçebilmektedir. Konsolidasyon bitince, drenaja izin verilmeden makaslama gerçekleştirilmiştir. Deneyin sonucunda zemine ait efektif dayanım parametreleri ( $c^{\prime}$ ve $\phi^{\prime}$ ) belirlenmiştir. Killi zeminlerin likit limit, plastik limit ve plastisite indislerinin belirlenmesi için de ASTM D431810E1 (2010) standardı dikkate alınmıştır.

\section{JEOLOJi}

Harmandalı Katı Atık Düzenli Depolama Sahası ve yöresinin jeoloji haritası Şekil 4 'te sunulmuştur. Sahada temel kayacını Üst Kretase-Paleosen yaşlı Bornova Karmaşığı oluşturur (Erdoğan, 1990). Birim, kumtaş1şeyl ardalanmasından oluşan bir matriks ile matriks içinde olistolit konumunda, değişik boyutlarda kireçtaşı blokları içerir. Zayıf kayaç özelliğindeki laminalı şeyller çok kıvrımlı ve kırıklı bir yapı sunar. Matriksin bir diğer bileşeni sağlam, ince - orta katman kalınlığına sahip kumtaşıdır. Katı atık depolama sahası içerisinde Neojen yaşlı tortul kayaçlara rastlanmamıştır. $\mathrm{Bu}$ nedenle, Üst Miyosen-Pliyosen yaş1 Yamanlar Volkanitleri'ne ait lav ve piroklastikler (aglomera ve tüfler) uyumsuzlukla doğrudan Bornova Karmaşığı üzerine gelir (Şekil 4 ve 5). Aglomeralar bloklu bir iç yapıya sahip, kolayca aşınabilen, zayıf kayaçlardır. Tüfler aglomeraların tabanında, yanal devamsız, ince bantlar şeklinde (1-5 m) uzanırlar. Andezitler katı atık depolama sahasının dışında, daha düşük topografik kotlarda yüzlekler vermiştir (Şekil 4).

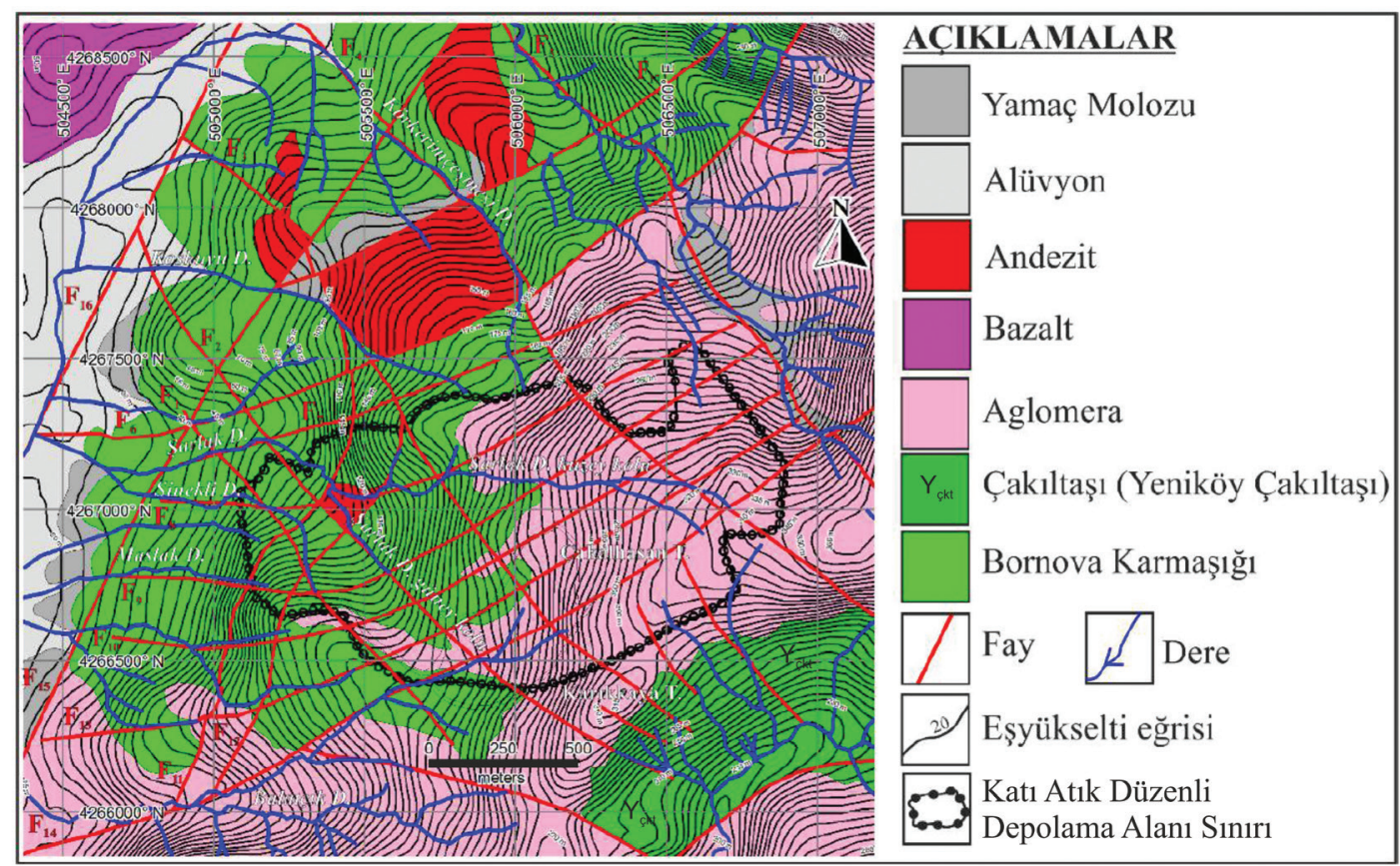

Şekil 4. İnceleme alanı ve yakın yöresinin 1/5000 ölçekli jeoloji haritası (Akbaş vd., 2011'den değiştirilerek).

Figure 4. 1/5000 scale geological map of study area and nearby vicinity (modified from Akbaşs et al., 2011). 
Katı atık depolama alanı ve yakın yöresi yoğun tektonik etkiye uğramış bir arazi görünümündedir (Şekil 4). İnceleme alanında üç farklı fay takımı belirlenmiştir. i) KDD-GBB uzanımlı, eğim atımlı normal faylar, ii) KBGD uzanımlı (K30-40B/50-60 B), eğim atımlı normal faylar, iii) $3 \mathrm{~m}$ düşey atıma sahip, her iki fay takımını kesen KD-GB uzanımlı ters faylar (Özellikle $\mathrm{F}_{12}$ fay1) K $25 \mathrm{D} / 74 \mathrm{~KB}$, seddeyi dar açıyla kesmekte ve Şubat-2013 heyelanının kayma dairesinin şekillenmesinde rol oynamıştır. Diğer taraftan, birinci takım faylarda ölçülen düşey atımlar 10-20 m arasındadır. Bu atımlar GD-KB yönünde sahaya basamaklı bir morfoloji kazandırmıştır.

\section{YAĞIŞ VE HEYELAN İLIŞKİSI}

2011, 2012 ve 2013 y1llarına ait yıllık yağış verileri sırasıyla $467.8 \mathrm{~mm}, 484.6 \mathrm{~mm}$ ve 584.4 mm olarak ölçülmüştür (Çiğli Meteoroloji Müdürlügü, 2013). Harmandalı Düzenli Katı Atık Depolama Sahası'nda 2013 yılının Şubat ayında bir heyelan meydana gelmiştir. Heyelanın meydana geliş tarihiyle yıllık yağış verileri karşılaştırıldığında, 2011 ve 2012 yıllarına ait yıllık yağış verilerinden yaklaşık $100 \mathrm{~mm}$ daha fazla yağışın 2013 yılında düştüğü görülmüştür (Şekil 6). Aralık-2012, Ocak ve Şubat-2013 aylık yağış verileri sirasıyla $128.4 \mathrm{~mm}, 134.0$ $\mathrm{mm}$ ve $132.6 \mathrm{~mm}$ olarak ölçülmüştür. Bu yağış verileri, 2012 ve 2013 yılları içinde ölçülmüş en yüksek aylık yağış verileridir.

\section{INKLINOMETRE OKUMALARI VE PRESIYOMETRE DENEYLERI}

Seddenin KB'de iki (SK-1 ve SK-2), GD'de bir adet olmak üzere (SK-3) üç adet inklinometre kuyusu açılmış, 08.03.2013 ve 28.09.2013 tarihleri arasinda toplam alt1 inklinometre okuması 9-12 günlük aralıklarla gerçekleştirilmiştir (Şekil 7). Şubat-2013'te kayma hareketi (heyelanın başlangıç tepkisi) meydana gelmiş, söz konusu kuyuların açılması ve inklinometre kuyusu olarak hazırlanıp okumalara başlanması Mart ayının ilk haftasını bulmuştur (08.03.2013). Kuyu sonları referans alınarak okunmuş deplasman değerleri sırasıyla $52 \mathrm{~mm}, 64.5 \mathrm{~mm}$ ve $35 \mathrm{~mm}$ 'dir (Şekil 7). SK-1 inklinometre kuyusunda, kayma dairesi yüzeyden $16 \mathrm{~m}$ derinlikte ölçülmüştür. SK-2 ve SK-3 inklinometre kuyularında ise bu derinlikler sirasıyla 22 m ve 31 m'dir (Şekil 8). Mart-2013'te açılmış bu üç inklinometre kuyusuna ait yanal yöndeki deformasyonların meydana geldiği derinlikler, Eylül-2016'da açılmış İK-1, İK-2, İK-3, İK-8 inklinometre kuyularında ve SK-4 sondaj kuyusunda gerçekleştirilen presiyometre deney sonuçları ve de sondajlara ait düşey zemin profilleri dikkate alınarak olası kayma modelinin gözlenebildiği heyelanın boy kesiti çıkartılmıştır (Şekil 8). Olası kayma dairesinin derinliğini ve şeklini belirlemek için yapılan diğer çalışmalar ise aşağıda sırasıyla anlatılmıştır.

Mart-2013'te seddenin batısında açılmış inklinometre kuyularında yeraltı suyu derinlikleri sirasıyla $2 \mathrm{~m}, 2 \mathrm{~m}$ ve $4.5 \mathrm{~m}$ olarak ölçülmüştür. Henüz yağışlar başlamadan Eylül-2016'da yaklaşık aynı lokasyonlarda açılmış inklinometre kuyularında ise (İK-1, İK-2, İK-3) YASS derinlikleri sirasıyla $5.3 \mathrm{~m}$, $6.8 \mathrm{~m}$ ve $5.3 \mathrm{~m}$ 'dir (Çizelge 2). Mart ayında alınmış YASS derinlikleri yüzeye daha yakın olarak ölçülmüştür. SK-4 sondaj kuyusu sedde ile katı atık şevi arasında sı ̆̆ bir hendekte yer almaktadır (Şekil 2). Katı atık sızıntı suları hendekte biriktiği için SK-4 kuyusunda su seviyesi yüzeye daha yakın konumdadır (1.4 m). SK-4 sondaj kuyusu heyelanın kayma mekanizmasının anlaşılması açısından en önemli kuyudur. Bu nedenle, kuyuda hem fay etkisi hem de kaymaya neden olan ve suya doygun koşullarda yer alan kil bandının varlığı kolaylıkla takip edilebilmektedir (Şekil 9). 


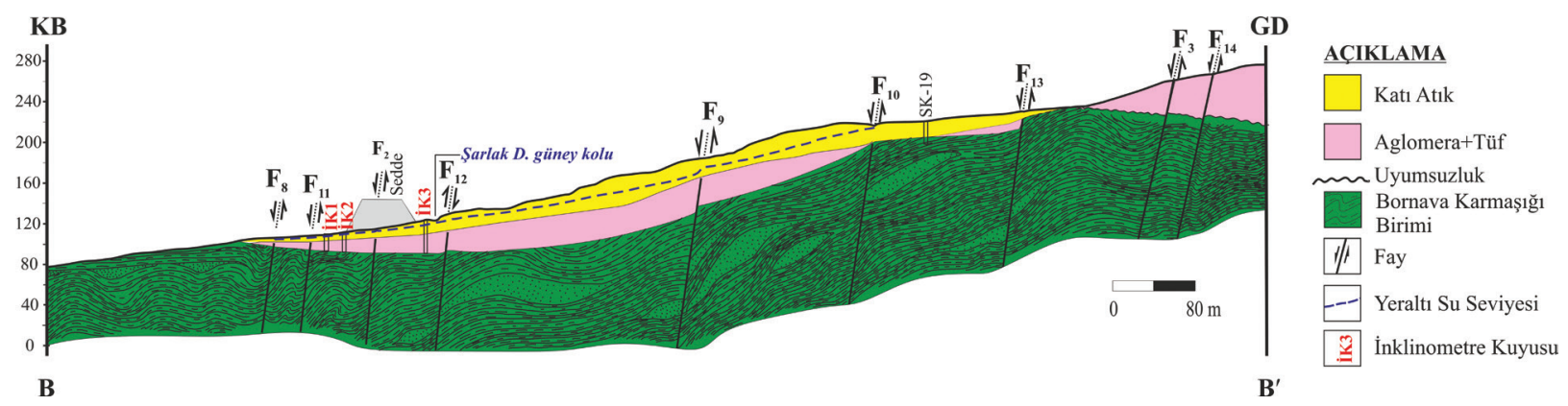

Şekil 5. $\mathrm{F}_{12}$ - fayı ve seddeyi kapsayacak şekilde KB-GD yönünde alınmış jeolojik kesit.

Figure 5. Geological cross-section taken in NW-SE direction involving $F_{12}$-fault and the embankment.

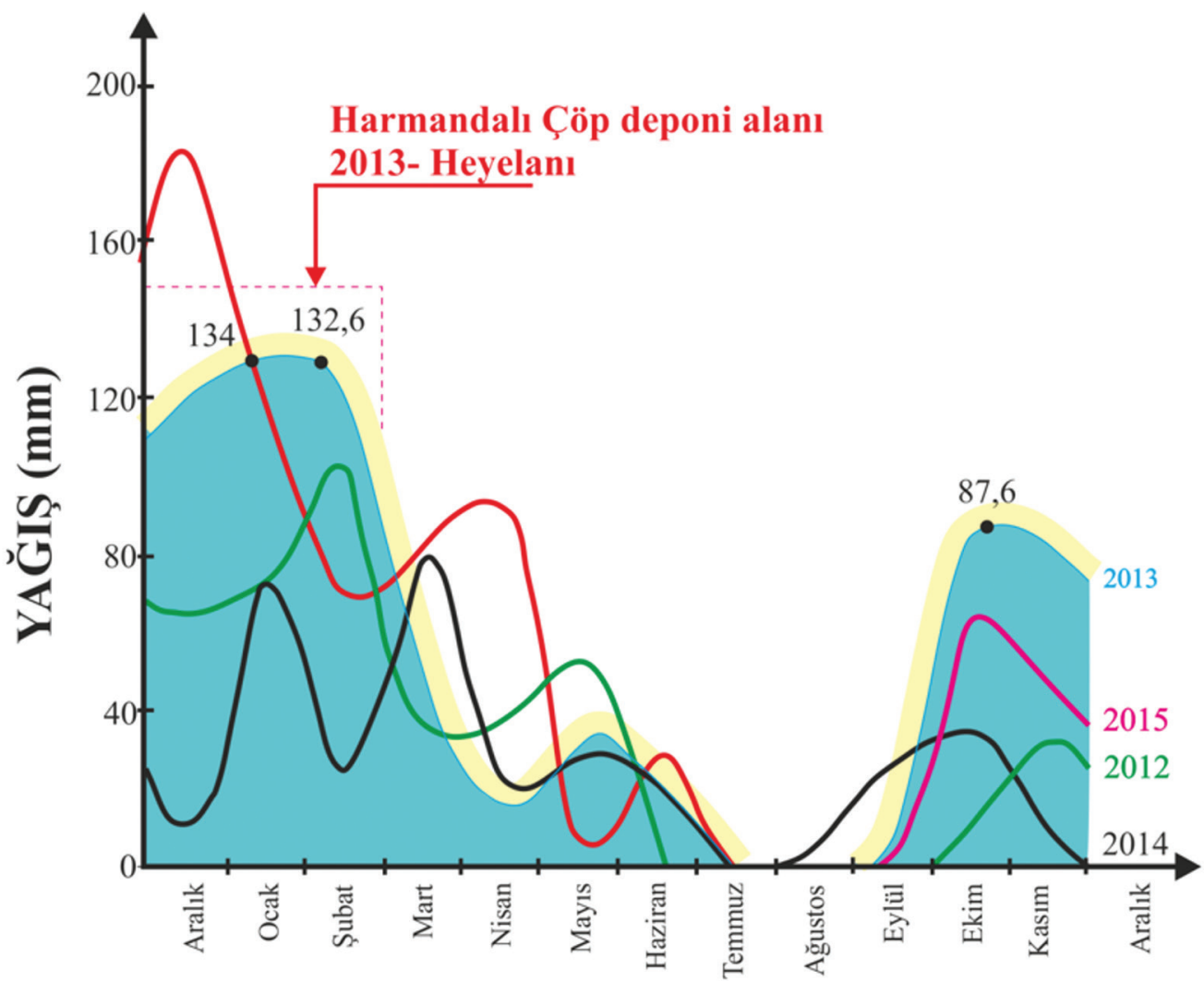

AYLAR

Şekil 6. 2012, 2013, 2014 ve 2015 yılları için aylara göre yağış miktarının değişimi.

Figure 6. The variations in the monthly precipitation for the years 2012, 2013, 2014, and 2015. 


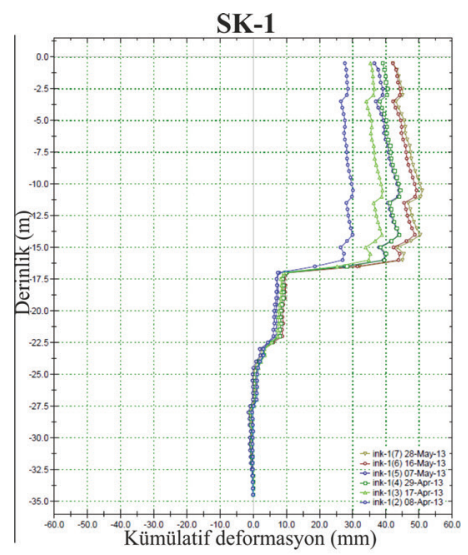

SK-2

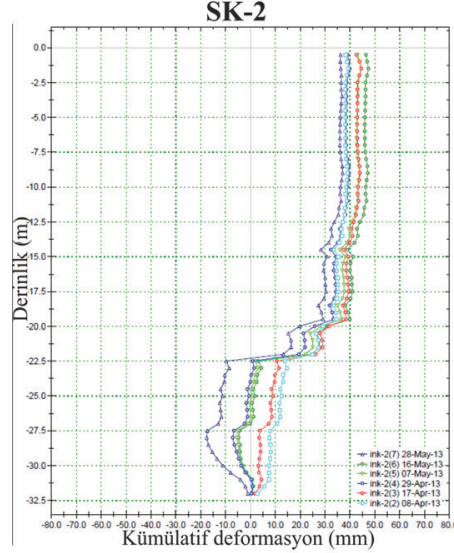

SK-3

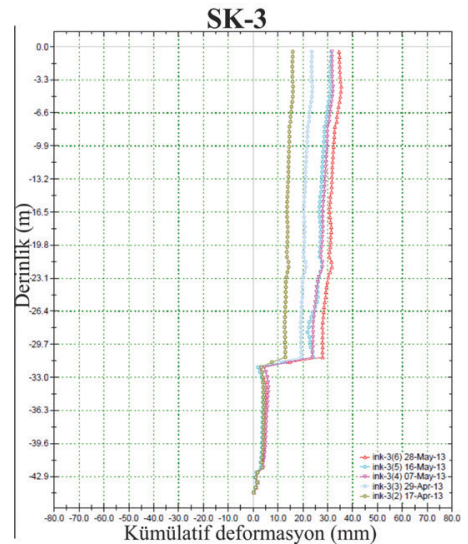

Şekil 7. Heyelanın kayma dairesinin yerini belirlemek üzere inklinometre kuyularında 2013 yılı Nisan ve Mayıs aylarında yapılan toplam altı okumanın grafik sunumları.

Figure 7. The graphs of total six readings made in April and May 2013 along inclinometer boreholes to determine the location of the surface.
Sondajlara ait loglar incelendiğinde, İK-3 inklinometre kuyusunda aglomeralara 17 m'de, seddeye en yakın konumda olan SK-4 kuyusunda ise $13.3 \mathrm{~m}$ 'de girilmiştir. $\mathrm{SK}-4$ kuyusundan elde edilen karotlarda $\mathrm{F}_{12}$ fayının etkisiyle ezilme, parçalanma izleri yoğun olarak gözlenmiştir (Şekil 9). SK-4 sondaj kuyusunda, Bornova Karmaşığı'na, 23 m'de, İK-3' de ise 36 $\mathrm{m}^{\prime}$ de girilmiştir. SK-4 sondajının kuyu ağız kotu $120.5 \mathrm{~m}, \mathrm{IK}-3$ kuyusunun ise $126 \mathrm{~m}$ 'dir (Şekil 8). $\mathrm{Bu}$ konumsal durum, $\mathrm{F}_{12}$ fayının yükselen bloğunun seddeye bakan tarafta, düşen bloğunun ise katı atık depolama alanına bakan kesiminde yer aldığına işaret etmektedir. $F_{12}$ fayı yüksek açılı bir ters faydır ve olasılıkla kayan kütleyi (hareket eden kütleyi) GD'dan sinırlamaktadır (Şekil 8).

Eylül-2016' da açılmış İK-1, İK-2, İK-3, İK-8 inklinometre ve SK-4 sondaj kuyularında presiyometre deney sonuçlarına göre belirlenmiş en zayıf zonlar, limit basınç $\left(\mathrm{P}_{\mathrm{L}}\right)$ ve elastisite modülü $\left(\mathrm{E}_{\mathrm{M}}\right)$ değerlerinin derinlikle değişimleri sırasıyla Şekil 10 ve $11^{\prime}$ de grafik olarak sunulmuştur. Olası kayma dairesinin geçtiği zon boyunca sondaj kuyularında okunan net limit basınç değerleri Çizelge 3'te verilmiştir. Heyelanın kayma dairesinin geçtiği zon boyunca net limit basinç değerlerinin 68-125 $\mathrm{kg} / \mathrm{cm}^{2}$ mertebesinde olduğu Çizelge 3 'ten anlaşılmaktadır. 


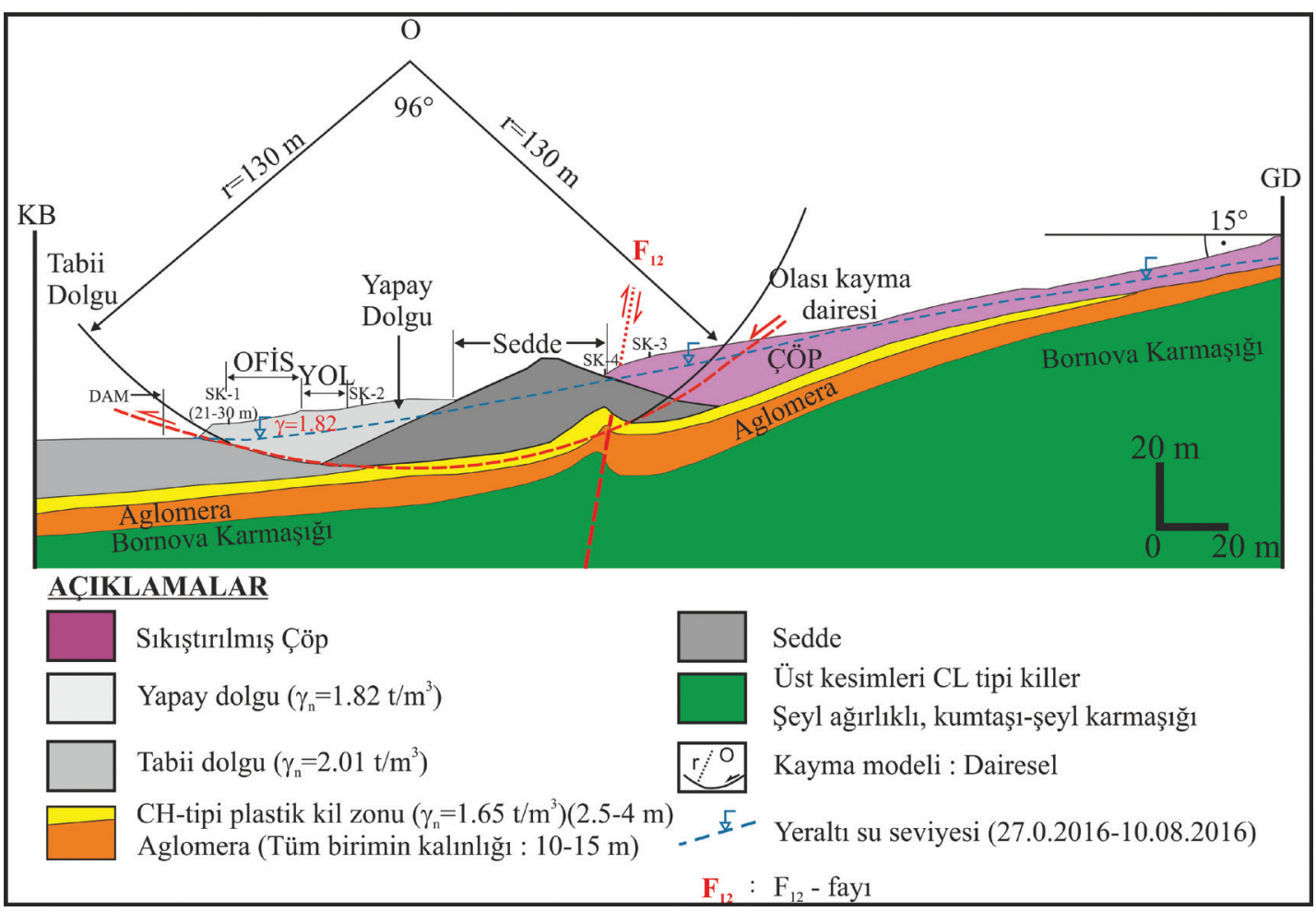

Şekil 8. Heyelanın 1/1000 ölçekli jeoteknik kesiti.

Figure 8. 1/1000 scale geotechnical cross-section of the landslide.

Çizelge 2. Sondaj kuyularında ölçülen su seviyesinin tabii zemin kotuna göre konumu ve derinlikleri (Eylül-2016'da açılmış sondajlar).

Table 2. The location of the water table level measured in boreholes relative to the ground level and their depths (boreholes drilled in September-2016).

\begin{tabular}{|c|c|c|c|c|c|}
\hline Malzeme & Sondaj No & YASS (m) & $\begin{array}{c}\text { Dolgu+ Katı atık } \\
\text { Kalınlığ } 1(\mathrm{~m}) \\
\end{array}$ & Fark (m) & $\begin{array}{c}\text { Su seviyesinin } \\
\text { konumu }\end{array}$ \\
\hline \multirow{3}{*}{$\begin{array}{c}\text { Katı atık yok, vasıfsız yüzey } \\
\text { dolgusu var }\end{array}$} & İK-1 & 5.30 & 3.00 & -2.30 & \multirow{3}{*}{$\begin{array}{c}\text { Tabii zemin } \\
\text { kotunun } \\
\text { altında }\end{array}$} \\
\hline & İK-2 & 6.80 & 0.30 & -6.50 & \\
\hline & $\mathrm{SK}-5$ & 2.00 & - & -2.00 & \\
\hline \multirow{7}{*}{$\begin{array}{l}\text { Sondajda yüzeyden itibaren } \\
\text { Katı atık + dolgu kesilmiş } \\
\text { daha sonra kaya birimine } \\
\text { girilmiştir. }\end{array}$} & İK-3 & 5.30 & 9.00 & +3.70 & \multirow{6}{*}{$\begin{array}{c}\text { Tabii zemin } \\
\text { kotunun } \\
\text { üzerinde }\end{array}$} \\
\hline & $\mathrm{SK}-4$ & 1.40 & 20.0 & +18.6 & \\
\hline & SK-6 & 16.8 & 17.6 & +0.80 & \\
\hline & SK-7 & 39.0 & 42.5 & +3.50 & \\
\hline & $\overline{\mathrm{I} K}-8$ & 17.8 & 20.6 & +2.80 & \\
\hline & SK-10 & 14.5 & 15.0 & +0.50 & \\
\hline & SK-9 & 20.0 & 20.0 & - & $\begin{array}{c}\text { Tabii zemin } \\
\text { kotunda }\end{array}$ \\
\hline
\end{tabular}

İK: İnklinometre kuyuları 
Kıncal, Kadakci Koca, Koca

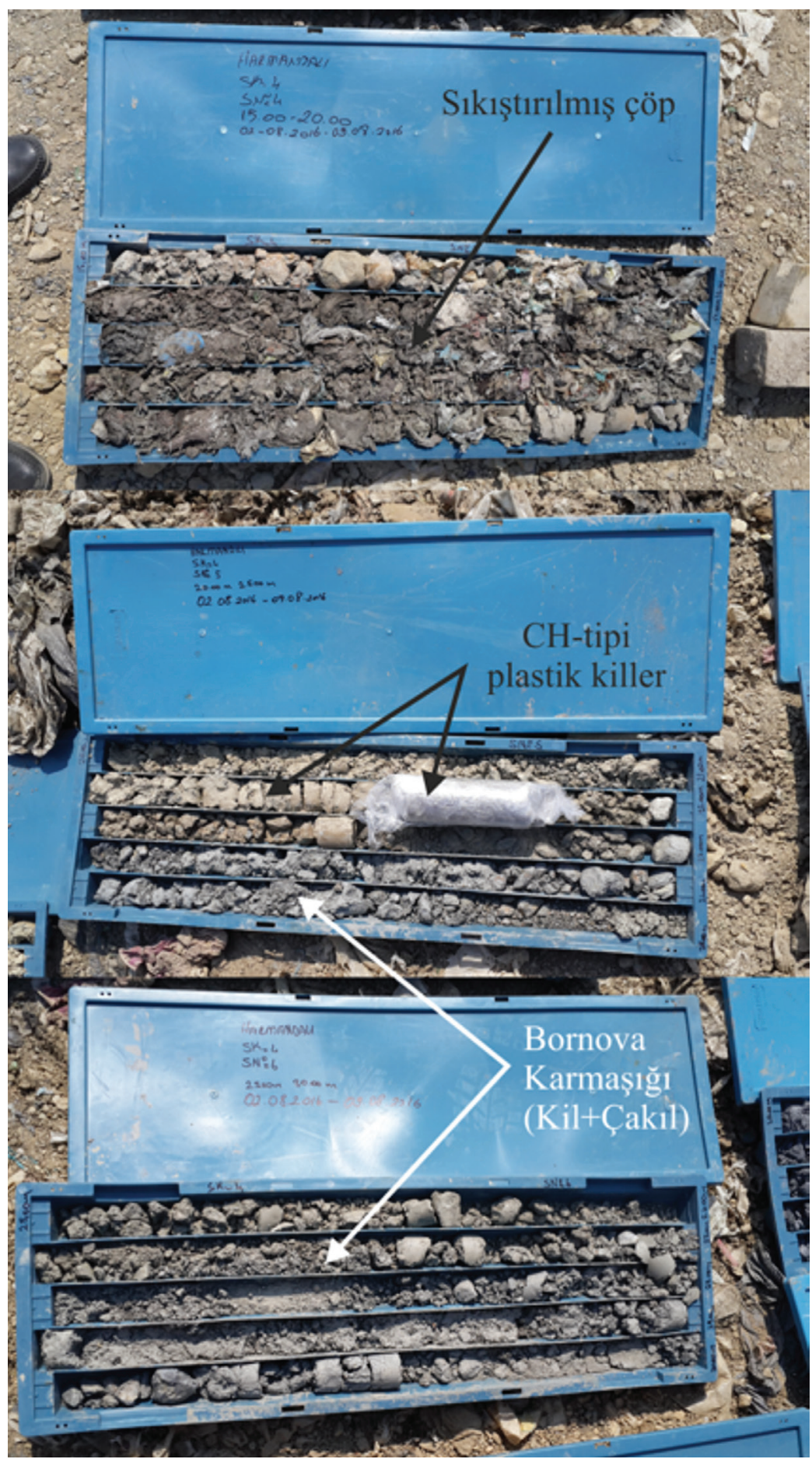

Şekil 9. $\mathrm{F}_{12}$ fayının etkisiyle deforme olmuş aglomeralar ve Bornova Karmaşı̆̆ı'na ait şeyller.

Figure 9. The deformed agglomerates due to $F_{12}$ fault and weathered shales of Bornova Melange. 


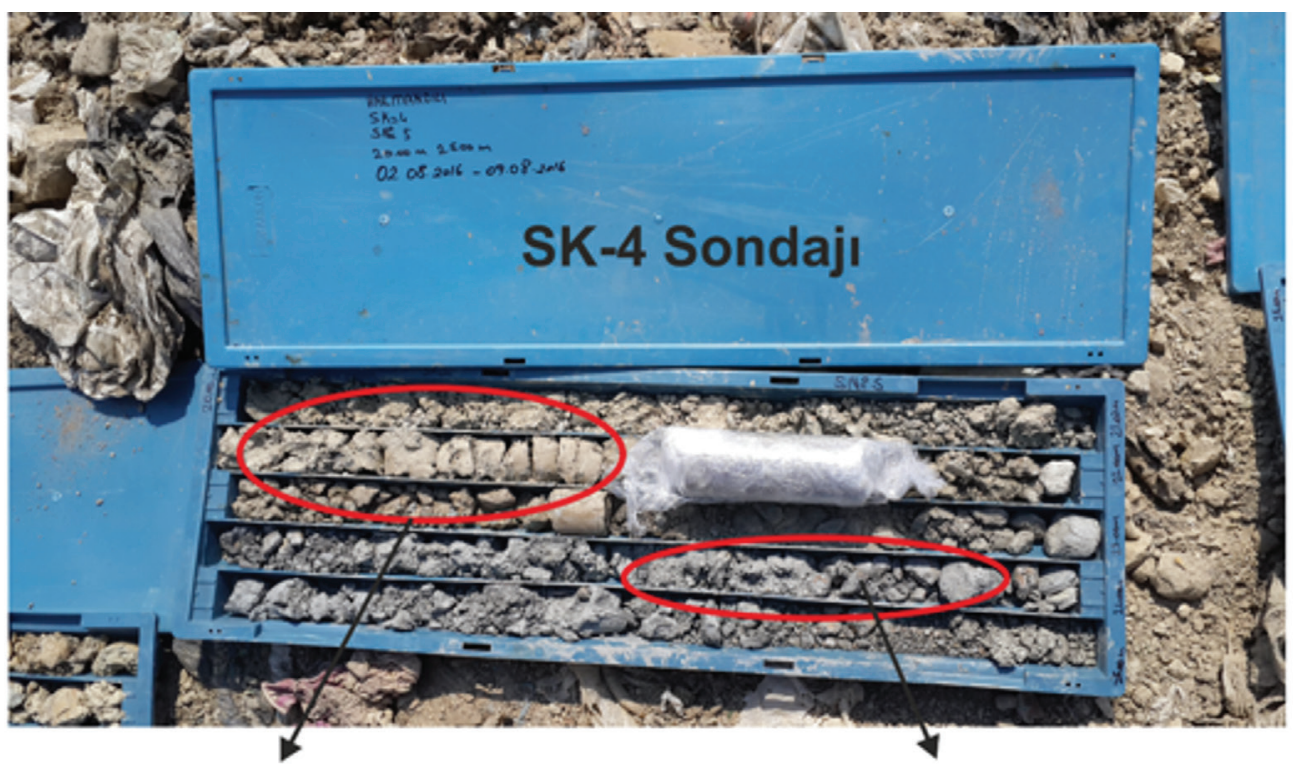

Volkanik k. ayrışma ürünü,

Heyelanın kayma andezit çakıllı, plastik killer.

dairesinin geçtiği zon.

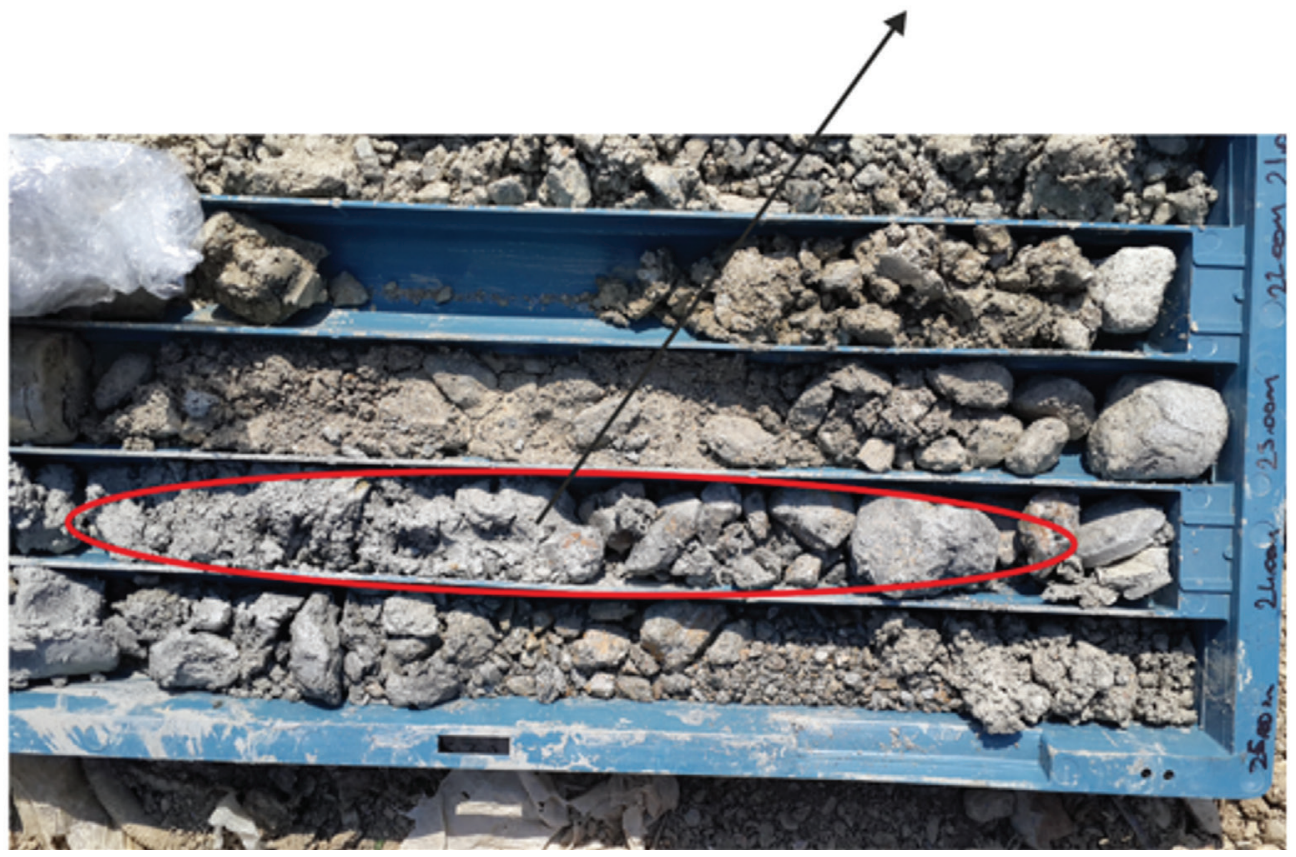

Şekil 9. devam ediyor.

Figure 9. to be continued. 
Çizelge 3. Kayma dairesinin geçtiği zon boyunca sondaj kuyularında gerçekleştirilen presiyometre deneylerinin sonuçları.

Table 3. The pressuremeter test results performed in the boreholes along the zone of circular slip surface.

\begin{tabular}{cccc}
\hline Sondaj No & $\begin{array}{c}\text { Ölçülen derinlik } \\
(\mathrm{m})\end{array}$ & $\begin{array}{c}\text { Net limit basıç } \\
\left(\mathrm{kg} / \mathrm{cm}^{2}\right)\end{array}$ & $\begin{array}{c}\text { Elastisite modülü } \\
\left(\mathrm{kg} / \mathrm{cm}^{2}\right)\end{array}$ \\
\hline IKK-1 & $4-6$ & $8.94-9.4$ & $81-125$ \\
\hline IKK-2 & $19.5-21.5$ & $\mathrm{~W}_{5}$ ve SCR $\leq \% 20$ & 185 \\
\hline İK-3 & $17-21$ & 11.0 & $81-84$ \\
\hline SK-4 & $20-23$ & 9.0 & $68-78$ \\
\hline
\end{tabular}

$\mathrm{W}_{5}$ : Tamamen ayrışmış kayaç, \%SCR (Sağlam karot verimi).

İK-2 inklinometre kuyusunda $19.5 \mathrm{~m}-21.5$ $\mathrm{m}$ arasında çok sık çatlaklı bir zon geçilmiştir (SCR $\leq \% 20)$, (Şekil 10). Bu zonda andezit kaya parçaları plastik killerle birlikte yer almaktadır. $\mathrm{Bu}$ nedenle, zon boyunca diğer kuyulardaki değerlerden daha yüksek net limit basinç (20-25 $\left.\mathrm{kg} / \mathrm{cm}^{2}\right)$ ve deformasyon modülü değerleri (185 $\mathrm{kg} / \mathrm{cm}^{2}$ ) elde edilmiştir. Kayma dairesinin geçtiği yüksek plastik kil zonu boyunca presiyometre baskın limit basınç değerleri $9.0-11.0 \mathrm{~kg} / \mathrm{cm}^{2}$ mertebesinde, deformasyon modülü değerinin ise $70-80 \mathrm{~kg} / \mathrm{cm}^{2}$ arasında olduğu belirlenmiştir. Şekil 8' de heyelanın kayma mekanizması ve olas1 kayma dairesinin geçtiği zon hem litolojilere hem de yeraltı suyu seviyesinin konumuna göre izlenebilmektedir. 2013 yılında açılmış inklinometre kuyularında yapılan okumalarla belirlenmiş kayma dairesinin geçtiği derinliklerle 2016'da açılmış kuyularda presiyometre deney sonuçlarından elde edilen zayıflık zonlarının derinlikleri örtüşmektedir.

Heyelanın kayma dairesi, sedde altındaki yüksek plastisiteli killerin yer aldığı zon boyunca, topoğrafik eğimle $\mathrm{KB}^{\prime}$ ye doğru ilerlemekte daha sonra, tabii zemin ve yapay dolgu zemin arasında yer alan dokanaktan geçmektedir (Şekil 8). Kayma dairesinin geçtiği yayın merkezi, Şekil 8'de gösterilmiş olan “O” noktası dikkate alındığında, seddenin büyük bir bölümünün kaymayı tetikleyici, küçük bir bölümünün de engelleyici bir rol üstlendiği anlaşılmaktadır. Seddenin bu konumu stabilite açısından da uygun olmayan bir durumdur.

Boya deneyleri: Sedde ile katı atı depolama alanı arasında yer alan hendekte (Kot: $118 \mathrm{~m}, \mathrm{SK}-4$ ve İK-3 kuyuları arasında) ve İK-8 inklinometre kuyusunun yer aldığ 1 (Kot:137 m) katı atık şevi basamağında boya deneyleri yapılmıştır. $\mathrm{Bu}$ deneylerin amacı, gerek inklinometre okumaları gerekse de presiyometre ölçümlerine ve de arazi gözlemlerine dayandırılarak belirlenmiş olası kayma dairesinin konumunun doğruluğunu onaylamak, hendekten ve üst kotlardan bırakılan boyalı suyun (Rodamin katk1l1, C.I.45170, $\mathrm{C}_{28} \mathrm{H}_{31} \mathrm{CIN}_{2} \mathrm{O}_{3}$ ), ofis binalarının arkasında yer alan dere içine erişip erişmediğini gözlemlemektir. Boyalı su SK-4 sondajının eteğindeki bataklık alandan 10.11.2016 tarihinde salınmıştır. 27.11.2016 tarihinde, 3-5 dakikalık çok kısa bir zaman diliminde su çıkışı dere içinde gözlenebilmiştir. Rodamin katkılı su, katı atık suyunun kahverengimsi gri renkle karışması nedeniyle, kırmızımsı pembe olan rengi bordoya dönüşmüş olarak dere içinde izlenmiştir. Rodamin içeren suyun izlenebilmesi, heyelanın kayma dairesinin, sedde gerisinde yer alan tabanı yüksek plastisiteli kil olan çukurluğa/hendeğe yakın olarak geçtiğini göstermektedir (Şekil 8). 


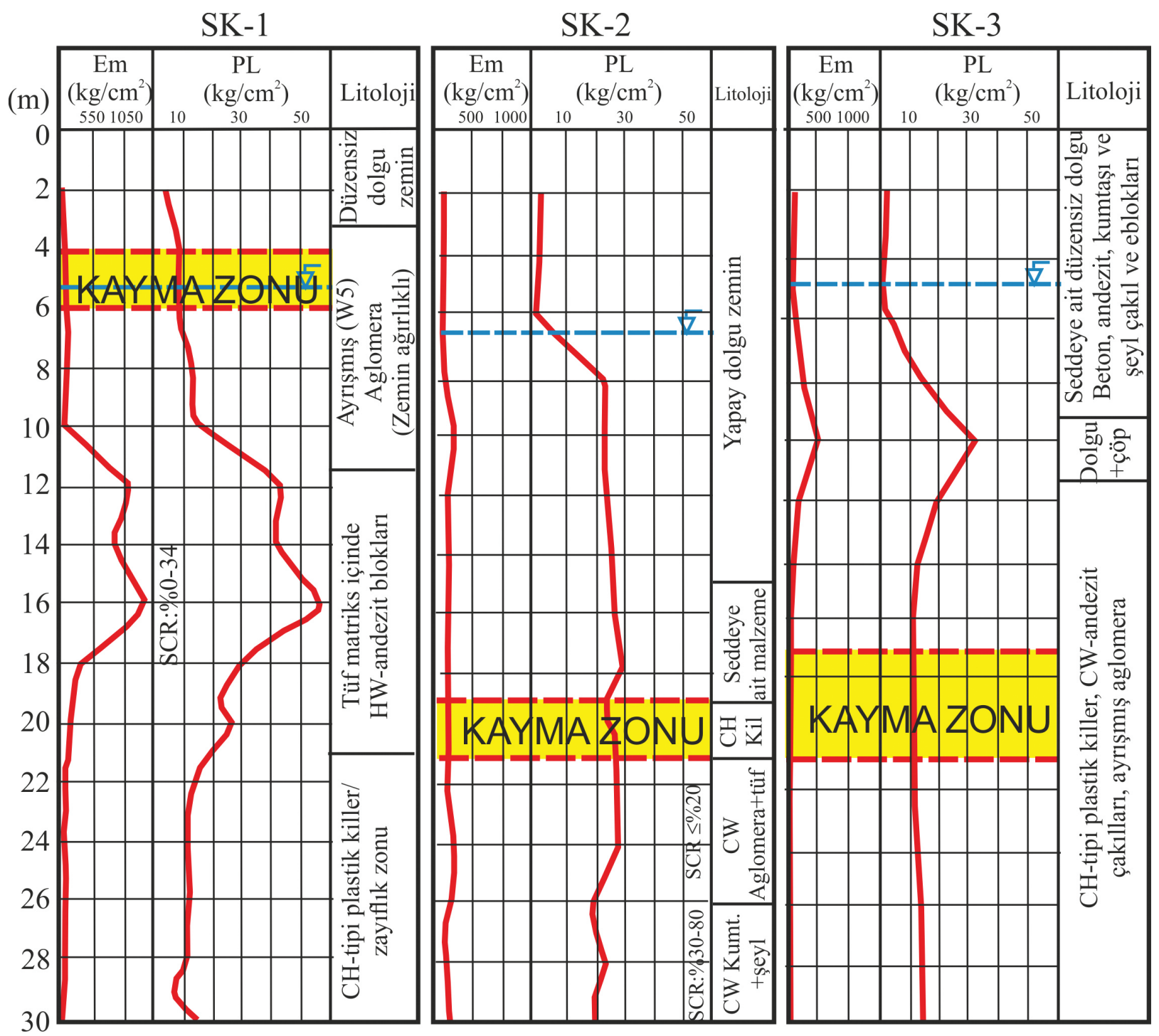

Şekil 10. İK-1, İK-2 ve İK-3 inklinometre kuyularında gerçekleştirilen presiyometre deney sonuçlarının derinlikle değişimi ve kayma zonlarının derinlikleri.

Figure 10. The variations in the pressiometer test results performed in the inclinometer boreholes IK-1, IK-2 and IK-3 with depth and the depth of slip zones. 


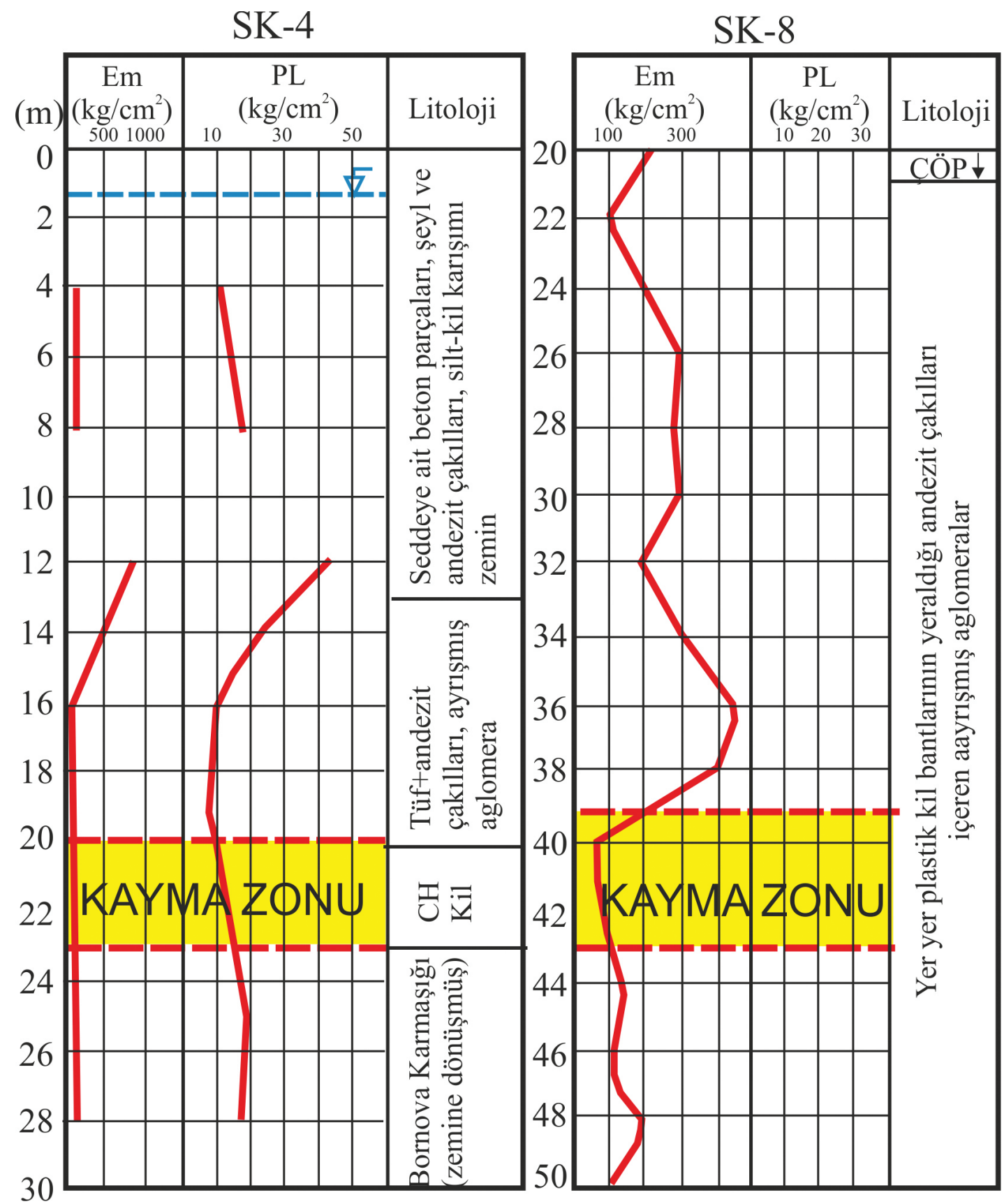

Şekil 11. SK-4 ve İK-8 sondaj kuyularında gerçekleştirilen presiyometre deney sonuçlarının derinlikle değişimi ve kayma zonlarının derinlikleri.

Figure 11. The variations in pressiometer test results performed in the inclinometer boreholes SK-4 and IK-8 with depth and the depth of slip zones. 


\section{KİLLERINN MÜHENDISSLIK ÖZELLIKKLERI}

Eylül-2016'da açılmış inklinometre kuyularından alınmış, örselenmiş (D) ve örselenmemiş (UD) zemin örnekleri üzerinde laboratuvar deneyleri yapılmış ve sonuçları Çizelge 4 'te toplu olarak sunulmuştur. Ayrıca alınan örneklerin kıvam durumları, doğal birim ağırlıkları, doğal su içerikleri, kıvam indisi (I) ve likitlik indisi ( $\mathrm{I}_{\mathrm{L}}$ ) değerleri Çizelge 5 'te verilmiştir. $\mathrm{Bu}$ çizelgede zeminlerin doğal su içeriklerinin plastik limit değerleriyle karşılaştırılması da görülmektedir. $\mathrm{Bu}$ karşılaştırma, doğal su içeriğindeki bir zeminin, plastik kıvamda olup olmadığının doğrudan değerlendirmesini vermektedir. Kohezyonlu zeminler plastik kıvama geçtiklerinde hacimce artış gösterirler. Hacimce genişleme $(\Delta V)$ nedeniyle zeminin hareket etme kabiliyeti de artar. $\mathrm{Bu}$ nedenle, zeminlerin k1vam durumlarının belirlenmesi, kütle hareketi oluşturma potansiyellerinin araştırılmasında önemlidir. İK-1, İK-3 ve İK-8 inklinometre kuyularından elde edilen zemin örneklerinde $\% \omega_{\mathrm{n}}>\% \omega_{\mathrm{PL}}$ durumu söz konusudur ve kayma eğilimi açısından bu zeminler göreceli daha uygundur. Buna ek olarak, kıvam indisi, $I_{c}:\left[\frac{W_{L L}-w_{n}}{w_{P I}}\right]$ ve likitlik indisi, $\mathrm{I}_{\mathrm{L}} ;\left[\frac{w_{n}-w_{P L}}{w_{P I}}\right]$; değerleri de bu durumu (Holtz ve Kovacs (1981)'e göre plastik kat1 özellikte zeminler) destekler niteliktedir, $0<\mathrm{I}_{\mathrm{L}}<1.0$, (Çizelge 5). $\mathrm{I}_{\mathrm{c}}$ değerlerine göre, İK-2 kuyusundan alınan örnek yarı katı $\left(I_{c}>1.0\right)$, diğer kil örnekleri ise plastik davranış göstermektedir $\left(0.25<\mathrm{I}_{\mathrm{c}}<1.0\right)$. Zemin örneklerinin plastisite kartı üzerindeki yerleri ve zemin sınıfları Şekil 12'de gösterilmiştir. Buna göre, İK-1, İK-2 ve İK-3 inklinometre kuyularından alınan zemin örneklerinin "yüksek plastisiteli kil, CH", İK-8 inklinometre kuyusundan alınan zemin örneğinin ise "düşük plastisiteli kil, "CL" olduğu anlaşılmaktadır (Şekil 12). Yüksek plastisiteli killer bünyelerine çok miktarda su alıp şişebilme, suyunu kaybettiklerinde de büzülme özelliğine sahiptir (Koca ve Türk, 1994; Koca, 1999; Kıncal vd., 2017). Yüksek plastisiteli killerin bünyelerine çok miktarda su aldıklarında, yumuşamaya bağlı olarak kesme dirençleri de çok düşer. Tüm bu özellikler $\mathrm{CH}$ türü killerin kayma potansiyelini arttırmaktadır. İK-1, İK-2 ve İK-3 inklinometre kuyularından alınmış örselenmemiş kil örnekleri üzerinde konsolidasyonlu-drenajlı (CD) direkt makaslama deneyleri yapılmıştır. Deneylerden elde edilen sonuçlar normal gerilme-makaslama gerilmesi grafiğine işlenerek Şekil 13'te sunulmuştur.

Andezitik tüf ayrışma ürünü yüksek plastisiteli killerin en büyük efektif içsel sürtünme açısı $\left(\phi^{\prime}\right), 14^{\circ}$ değerine kadar düşmekte ve katı atık yığınlarına taban oldukları lokasyonlarda kaymaya hassas zonlar oluşturmaktadırlar. Killerin kohezyon değerleri ise doğal su içeriklerinde sıfıra yakındır (5 - $12 \mathrm{kPa})$, (Şekil 13 ve Çizelge 6). Normal konsolide killerde $\tau_{f}=\sigma \tan \phi^{\prime}$ eşitliği, $\mathrm{c}^{\prime} \approx 0$ olduğundan doğrudan dikkate alınabilir. Kohezyonun sifir veya sifira yakın değerlerde olması kaymayı arttırıcı yönde bir etki yaratmaktadır. 

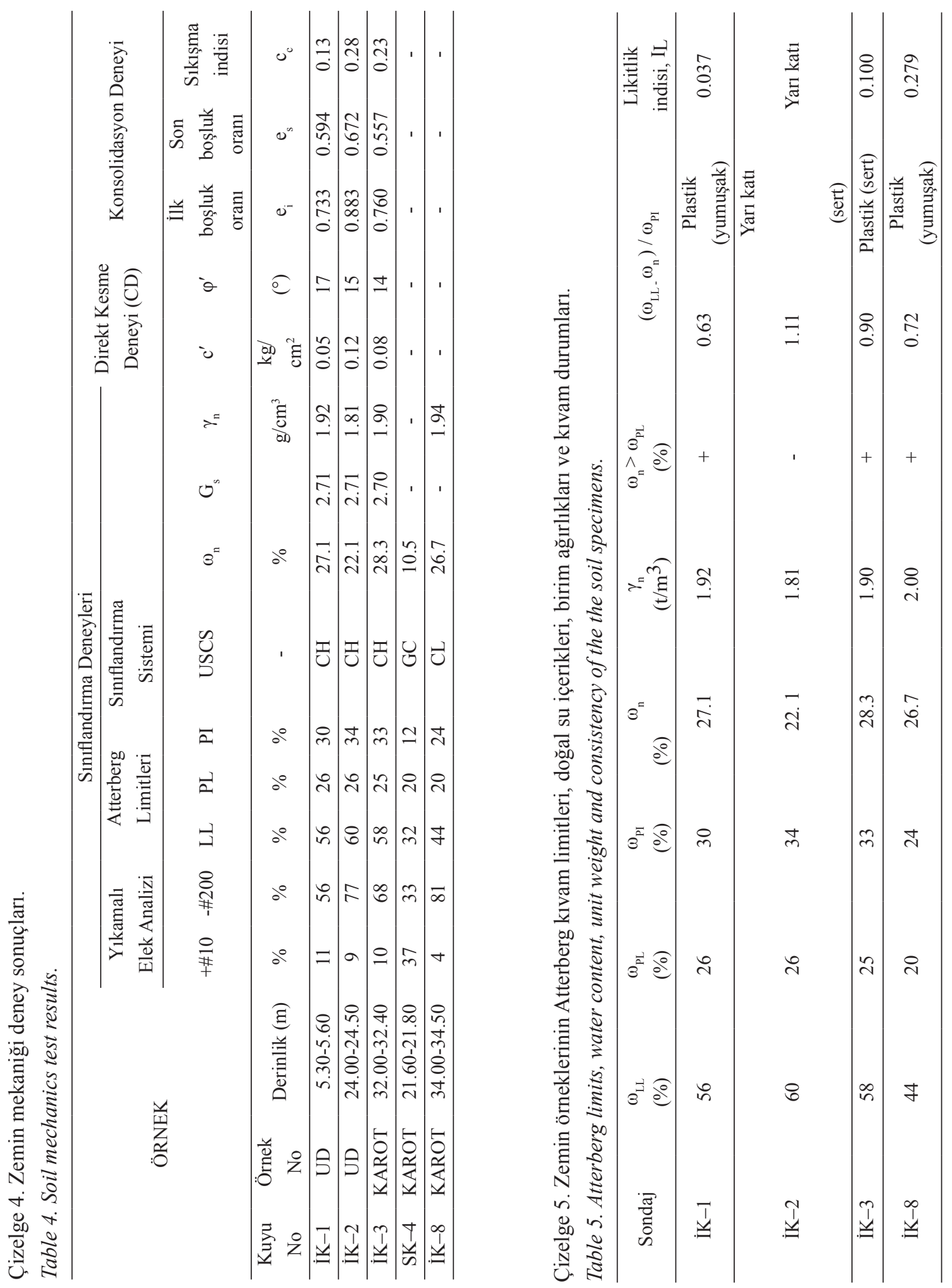


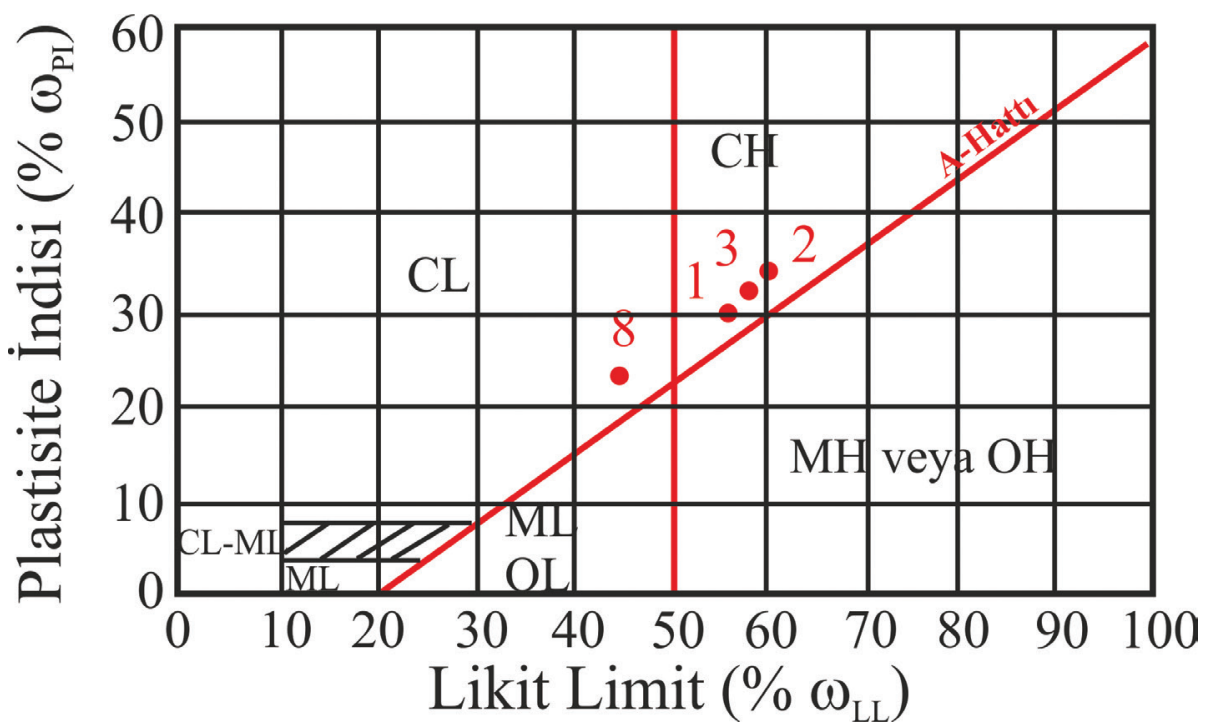

Şekil 12. İK-1, İK-2, İK-3 ve İK-8 sondaj kuyularından elde edilen zemin örneklerinin plastisite kartı üzerindeki yerleri.

Figure 12. The locations of the soil specimens taken from $\dot{I} K-1, \dot{I} K-2, \dot{I} K-3$, and $\dot{I} K-8$ boreholes on the plasticity chart.

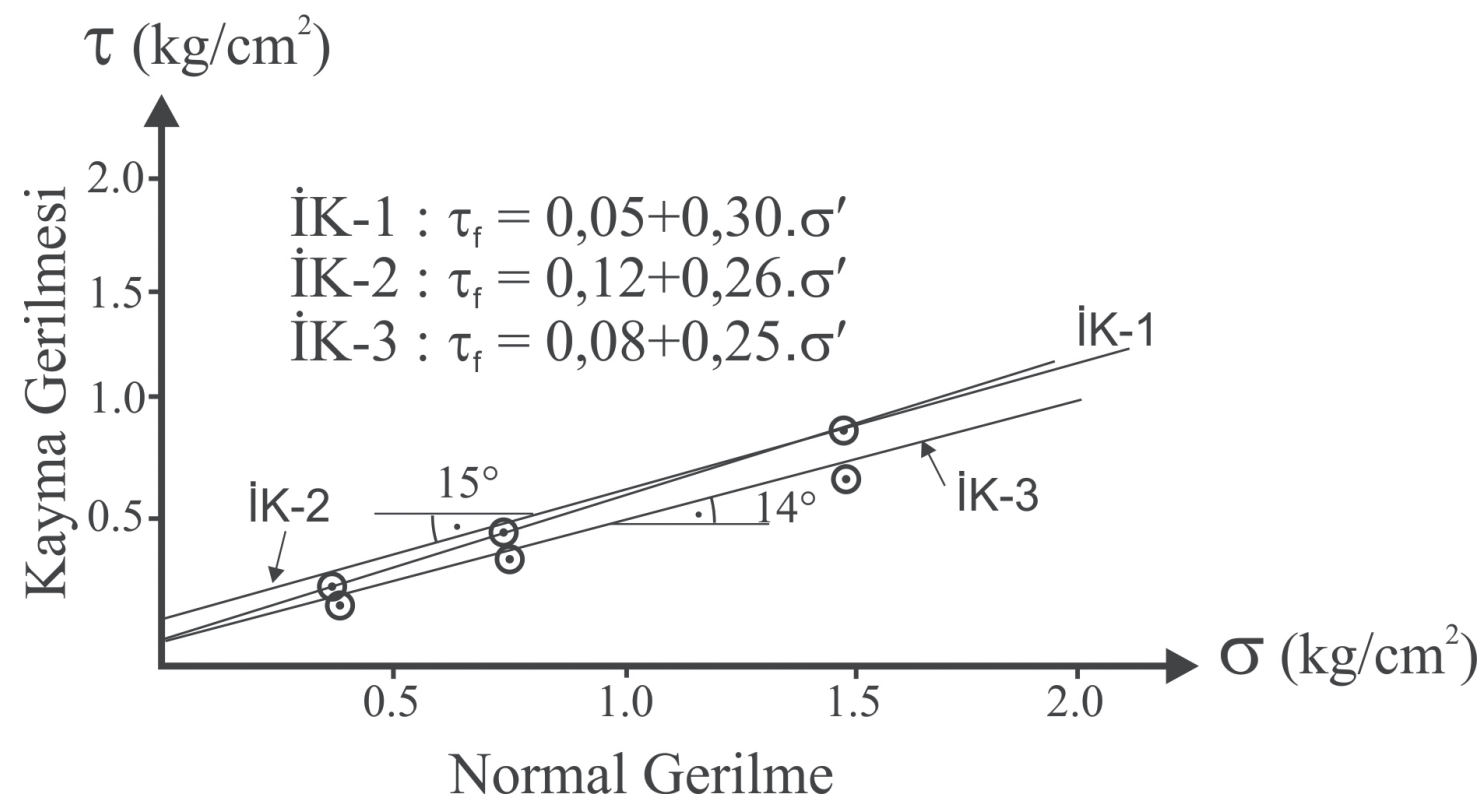

Şekil 13. Andezitik tüf ayrışma ürünü yüksek plastisiteli killere ait normal gerilme ve kesme gerilmesi ilişkisi.

Figure 13. The relationship between normal stress ve shear stress for the high plasticity clay derived from weathering of the andesitic tuff. 
Kıncal, Kadakci Koca, Koca

Çizelge 6. Yüksek plastisiteli killere ait kesme deneyi sonuçları.

Table 6. Shear test results of the high plasticity clays.

\begin{tabular}{ccccccc}
\hline Örnek & Kivam durumu & Kilin türü & $\begin{array}{c}\text { Doğal birim } \\
\text { hacim ağıllk } \\
\left(\mathrm{kN} / \mathrm{m}^{3}\right)\end{array}$ & $\begin{array}{c}\text { Efektif içsel sürtünme } \\
\text { açısı, } \phi\left(^{(}\right)\end{array}$ & $\begin{array}{c}\text { Efektif } \\
\text { kohezyon } \\
\left(\mathrm{kg} / \mathrm{cm}^{2}\right)\end{array}$ & $\begin{array}{c}\omega_{\mathrm{n}} \\
(\%)\end{array}$ \\
\hline İK-1 & Plastik & CH & 19.2 & 17 & 0 & 27.1 \\
\hline İK-2 & Yarı kat1 & CH & 18.1 & 15 & 0.12 & 22.1 \\
\hline İK-3 & Plastik & CH & 19.0 & 14 & 0.10 & 28.3 \\
\hline
\end{tabular}

\section{Konsolidasyon Deneyleri}

Andezitik tüf ayrışma ürünü yüksek plastisiteli killer $(\mathrm{CH})$ sedde altında, seddenin kret kotundan itibaren maksimum $20 \mathrm{~m}$ derinlikte yer almaktadır. Seddenin eteklerinde bu derinlik daha da düşmektedir (12 m). Sedde altında yer alan bu killer ofis binalarına doğru (GD'den KB'ye doğru) giderek kalınlıkları azalan bir şekilde konumlanmıştır. Kil bandının kalınlığı 2.5-4 m arasında değişmektedir. Killi zeminlerin sabit gerilmeler altında, zamana bağlı bünyelerindeki suyu atarak sıkışmalarına konsolidasyon denir. Bu zaman dilimi içerisinde, suya doygun kil bandında yavaş yavaş oluşan efektif gerilme artışı seddede zamanla oturmaya neden olmuştur. İK-1, İK-2 ve İK-3 inklinometre kuyularından, farklı derinliklerden elde edilen zemin örnekleri üzerinde konsolidasyon deneyleri gerçekleştirilmiştir (Şekil 14). Ayrıca İK-1, İK-2 ve İK-3 inklinometre kuyularından elde edilen zemin örneklerinin konsolidasyon deney sonuçları Çizelge $7^{\prime}$ de toplu olarak verilmiştir. Konsolidasyon deneyinde yüklemeler sirasinda $0.25,0.40,1.0,2.0,4.0$ ve $8.0 \mathrm{~kg} /$ $\mathrm{cm}^{2}$ gerilmeler uygulanmıştır (Şekil 14). Her uygulamada oluşan kademedeki boy değişimi $\left(\Delta \mathrm{H}_{i}\right)$ kaydedilmiştir. Kademedeki boşluk oranı değişimleri hesaplanmıştır.
$\Delta e_{i}=\Delta H_{i} / H_{\text {son }}$

Konsolidasyon deney sonuçlarını gösteren e- $\log$ P grafiği üç deney için ayrı ayrı elde edilmiştir (Şekil 14).

Sedde altında yer alan yüksek plastisiteli killerde meydana gelen oturma miktarları Çizelge 7'deki veriler yardımıyla hesaplanmıştır. Sedde altında yer alan kil bandının kalınlığ 2.5-4.0 m arasında değişmektedir $(2.5 \mathrm{~m}$ $\left.\leq \mathrm{H}_{\mathrm{o}} \leq 4.0 \mathrm{~m}\right)$. Seddenin yüksek plastisiteli kil bandına uyguladığı sabit gerilme değeri aralığ $\Delta \sigma=\mathrm{H}_{\text {sedde }} \times \gamma_{\text {kaya bloğu }}, \Delta \sigma_{\text {mak }}=20 * 2.1=42 \mathrm{t} / \mathrm{m}^{2}$ ve $\Delta \sigma_{\min }=12 * 2.1=25 \mathrm{t} / \mathrm{m}^{2}$ olarak alınabilir. Sedde eğimli bir yüzeye sahip olduğudan $\mathrm{H}_{\text {sedde }}$ yüksekliği de değişmektedir. $\mathrm{Bu}$ nedenle, $\Delta \sigma$ değeri $25-42 \mathrm{t} / \mathrm{m}^{2}$ arasında değerler almaktadır. Sedde tabanında yer alan yumuşak kıvamdaki, yüksek plastisiteli killer, normal konsolide (NK) killerdir $\left(\sigma_{0}{ }^{\prime}=\sigma_{c}{ }^{\prime}\right)$. Şekil $14^{\prime}$ te verilen İK-1, İK-2 ve İK-3 eğrilerinden killerin ön konsolidasyon basınçlarının $1.10 \leq \sigma_{c}{ }^{\prime} \leq 2.05 \mathrm{~kg} / \mathrm{cm}^{2}$ aralığında değiştiği görülmektedir. SK-4 konumunda açılan sondajın zemin profilinde kil bandının yer aldığı seviyedeki efektif gerilmeler yaklaşık 1.0 $\mathrm{kg} / \mathrm{cm}^{2}$, İK-2' de benzeri seviyelerde ise yaklaşı $\mathrm{k}$ $2.0 \mathrm{~kg} / \mathrm{cm}^{2}$ mertebesindedir $\left(1.0 \leq \sigma_{0}{ }^{\prime} \geq 2.0 \mathrm{~kg} /\right.$ $\mathrm{cm}^{2}$ ). Bir diğer anlatımla, aşırı konsolidasyon oranı, $\mathrm{AKO}=\sigma_{c}^{\prime} / \sigma_{0}^{\prime}=1$ durumu söz konusudur 
(NK). Her sondaj konumundan elde edilen plastik kil bandı kalınlıkları $2.5 \mathrm{~m}$ ve $4.0 \mathrm{~m}$ için konsolidasyon oturmaları Eşitlik 3 kullanılarak ayrı ayrı hesaplanmıştır. Konsolidasyon oturmaları minimum $13.42 \mathrm{~cm}\left(\mathrm{SK}-4^{\prime} \mathrm{de}, \sigma_{0}^{\prime}=\right.$ $1.0 \mathrm{~kg} / \mathrm{cm}^{2}$ ve $\mathrm{H}_{\mathrm{o}}=2.5 \mathrm{~m}$ için), maksimum 56.67 $\mathrm{cm}\left(\mathrm{IK}-2^{\prime} \mathrm{de}, \sigma_{0}^{\prime}=2.0 \mathrm{~kg} / \mathrm{cm}^{2}, \mathrm{H}_{\mathrm{o}}=4.0 \mathrm{~m}\right.$ için $)$ elde edilmiştir.

Çizelge 7. Konsolidasyon deney sonuçları

Table 7. Consolidation test results.

\begin{tabular}{|c|c|c|c|c|}
\hline Sondaj no & Başlangıç boşluk oranı $\left(\mathrm{e}_{0}\right)$ & $\begin{array}{l}\text { Son boşluk oranı } \\
\left(\mathrm{e}_{\mathrm{s}}\right)\end{array}$ & $\Delta \mathrm{e}$ & S1kışma indisi $\left(\mathrm{c}_{\mathrm{c}}\right)$ \\
\hline$\dot{\mathrm{I} K}-1$ & 0.733 & 0.594 & 0.139 & 0.13 \\
\hline$\dot{\mathrm{I} K}-2$ & 0.883 & 0.672 & 0.211 & 0.28 \\
\hline İK-3 & 0.760 & 0.557 & 0.203 & 0.23 \\
\hline
\end{tabular}

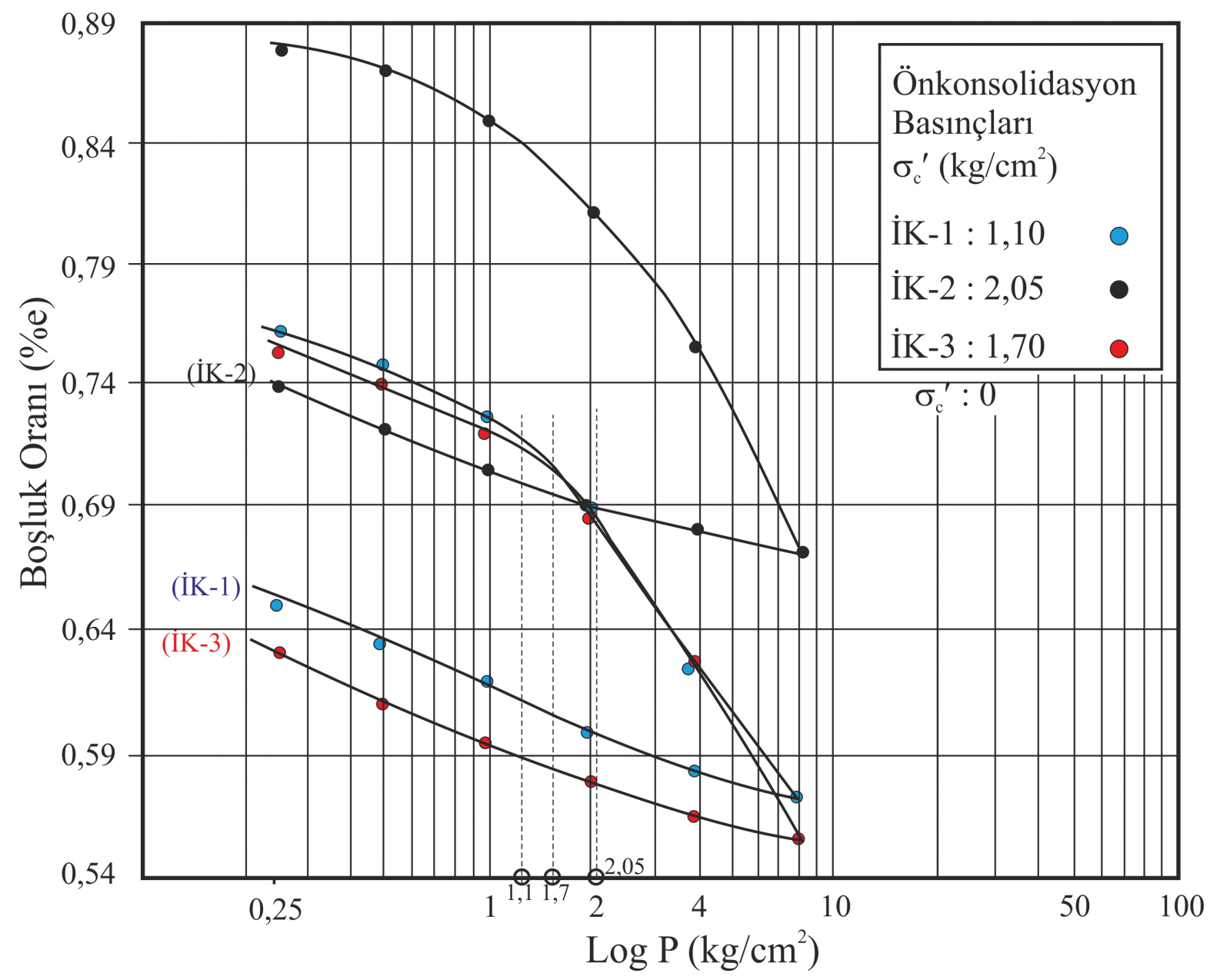

Şekil 14. Boşluk oranı (e)-Log $\mathrm{P}\left(\mathrm{kg} / \mathrm{cm}^{2}\right)$ grafiği.

Figure 14. Void ratio (e)-Log $P\left(\mathrm{~kg} / \mathrm{cm}^{2}\right)$ graph. 
Kil bandında meydana gelen oturmalar drenaj boru hattının işlevini tamamen yitirmesine neden olmuştur. Oturmaların sonucunda sedde yamaçlarında kabarma şeklinde gelişen yüzey deformasyonları meydana gelmiştir (Şekil 15). Sedde civarında oluşan deplasmanların önemli bir bölümünün oturma kaynaklı olduğu ortaya çıkmaktadır.

\section{TARTISYMA VE SONUÇLAR}

Şubat-2013 ve Nisan-2013 tarihlerinde sürekli, ancak yavaş gelişen kayma hareketinin öncesinde meydana gelen jeoteknik olaylar dizini aşağıda anlatıldığı gibi seyretmiştir. Sedde tabanında, seddenin kretinden maksimum 20 $\mathrm{m}$ derinde, $8^{\circ}-10^{\circ}$ batıya eğimli bir şekilde yataklanmış yüksek plastisiteli yumuşak killerde $(\mathrm{CH})$, seddeye ait dolgu yükleri altında 64.5 mm'ye erişen konsolidasyon oturmalarının meydana geldiği tahmin edilmiştir. 2010'dan 2013'e kadar geçen üç y1llık zaman diliminde (seddenin yapımından konsolidasyonunu tamamlamasına kadar geçen zaman diliminde) bu oturmaların büyük bir kısmının tamamlandığ 1 düşünülmüştür.

Yüksek oturmaların sonucunda, sedde yamaçlarında kabarma şeklinde gelişen yüzey deformasyonları ortaya çıkmıştır (Şekil 15). Normal konsolide, yüksek plastisiteli kil bandında meydana gelen oturmaların sonucu olarak, sedde altında yeralan atık su drenaj borularında hasarlar oluşmuştur. Drenaj borularında bükülmeler ve eğrilmeler meydana gelmiş ve zamanla işlevlerini kaybetmişlerdir. Böylece, sedde altından atık su drenajı tam olarak mümkün olamamıştır. Drene edilemeyen katı atık ve yüzey suları sedde gerisinde birikmiştir. Özellikle yağışlı aylar sonrasında, sedde ile katı atık depolama alanı arasında kalan çukurluk bölgede suya doygun koşulların oluştuğu, su seviyesi ölçümleriyle belirlenmiştir. Buna ek olarak, bu alanın yaz aylarında da bataklık halinde kaldığı gözlenmiştir. Biriken katı atık ve yüzey suları sedde arkasında baraj etkisi yapmakta, buna ek olarak, bu sular kontrolsüz bir şekilde kayma dairesi boyunca, hidrolik eğim yönünde KB'ye doğru (ofis binalarına doğru) sızmaktadır. Katı atık ve yüzey suları seddenin ve ana nakliye yolunun altından geçmekte, ofis binalarının arka tarafinda yer alan bir dereden deşarj olmaktadır. Rodamin katkılı su kullanarak yapilan boya deneyleri, kayma dairesi boyunca su sızıntılarının olduğunu kanıtlamıștır (Şekil 16).

$\mathrm{Su}$ seviyesi, yağışlar öncesinde $\mathrm{SK}-4$ kuyusunda $1.40 \mathrm{~m}$ olarak ölçülmüştür. Kat1 atık düzenli depolama sahası Aralık ve Şubat2013'te art arda çok yüksek yağışlar almıştır (134 mm ve $132.6 \mathrm{~mm}$ ). Bu yağışlarla birlikte YASS yüzeye çok yaklaşmış ve 18 Şubat 2013 tarihinde mevcut ortam tamamen suya doygun zemin koşullarına geçmiştir. Suya doygun zemin koşullarında, artan boşluk suyu basıncının $\left(\mathrm{u}_{\mathrm{w}}\right)$ yönü yüzeye doğrudur. $\mathrm{Bu}$ nedenle, kayma yüzeyi boyunca gelişen makaslama dayanımında $\mathrm{u}_{\mathrm{w}}$ kadar azalmalar meydana gelmiştir $\left(\tau=\mathrm{c}^{\prime}+\right.$ $\left.\left(\sigma-u_{w}\right) \tan \varphi^{\prime}\right)$. Bu durum kaymanın nedenlerinden biridir. Buna ek olarak, sedde gerisinde biriken sular baraj etkisi yapmış ve su seviyesinin yükselmesine bağlı olarak artan su basıncinın meydana getirdiği ek itki kuvveti $\left(\mathrm{u}_{\mathrm{w}}=15.5^{*} 1.0\right.$ $=15.5 \mathrm{t} / \mathrm{m}^{2}$ ) seddeyi KB'ye doğru kaydırıcı yönde etkilemiştir (Şekil 16). Sedde gerisinde meydana gelen hidrostatik su basıncının yükselmesi, drene edilemeyen katı atık ve yüzey sularının sedde altındaki yüksek plastisiteli kil bandı üzerinden, hidrolik akım yönünde ana nakliye yoluna ve ofis binalarına doğru sızması (Şekil 16), sedde gerisinde ve altında konumlanmış tüm zeminlerin suya doygun koşullara erişmesi sonucunda, Şubat-2013'te kütlenin başlangıç tepkisi olarak ilk kayma hareketi başlamıştır. 2013 yılı Nisan ve Mayıs aylarında gerçekleştirilen inklinometre ölçümlerinden kayma hareketinin bir süreliğine daha devam ettiği anlaşılmıştır. 


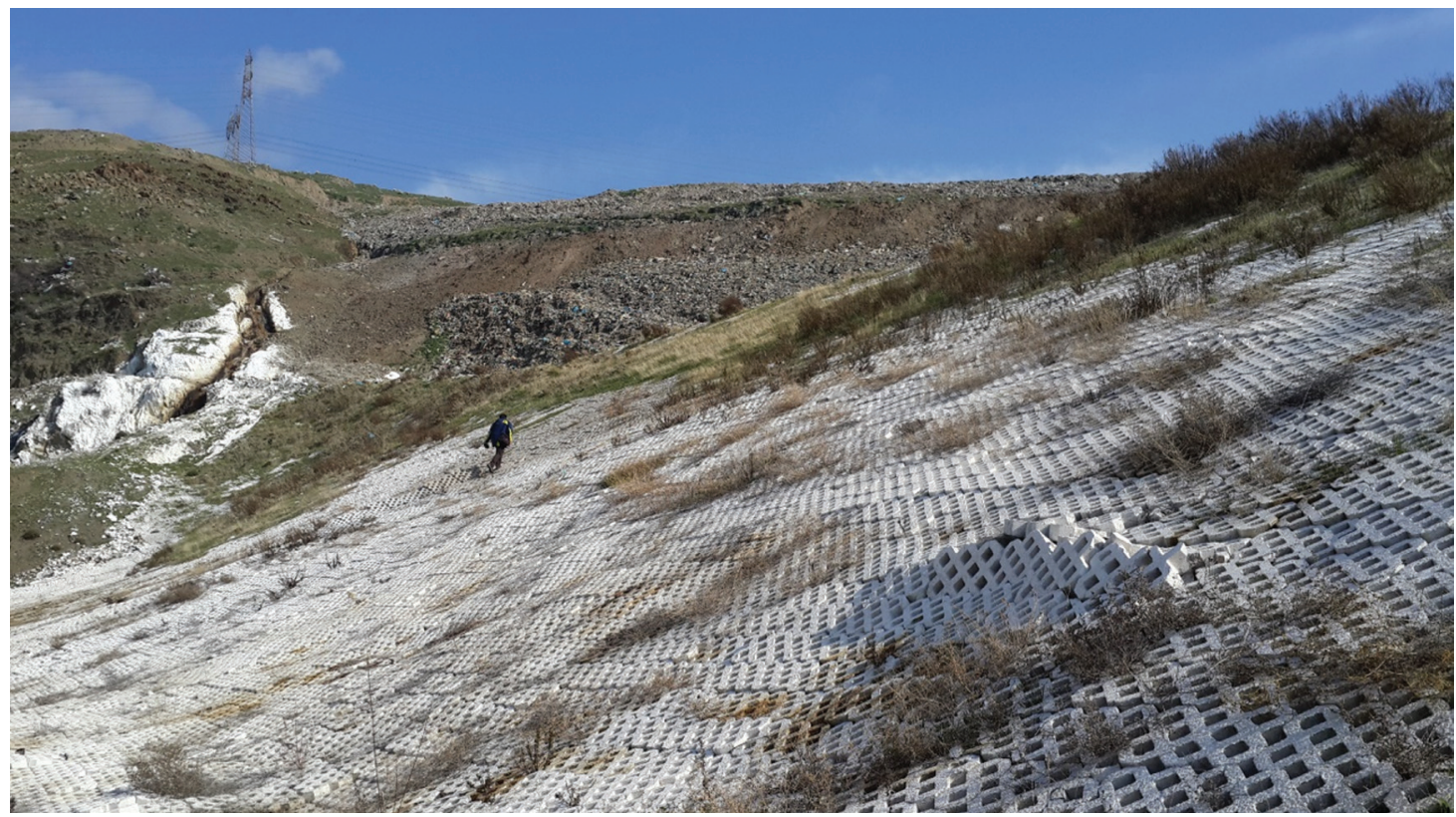

Şekil 15. Sedde üzerindeki kabarmalar.

Figure 15. Bucklings on the embankment.

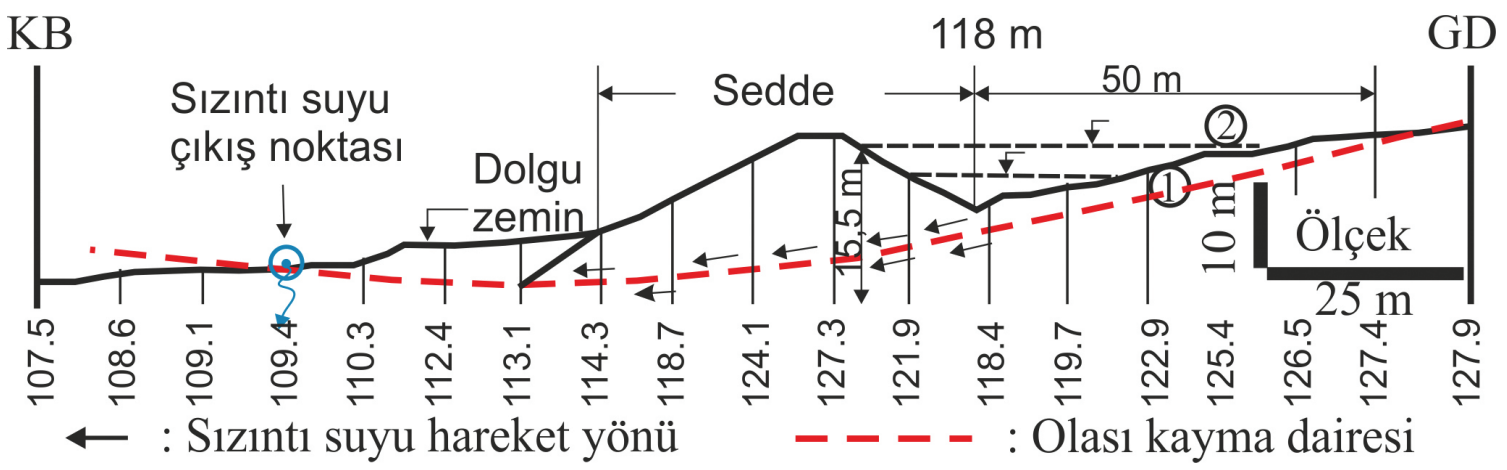

Şekil 16. Sedde gerisinde katı atık sızıntı ve yüzey sularının birikerek baraj etkisi oluşturması, su seviyesinin mevsimsel olarak değişimi (1 ve 2) ve olası kayma dairesinin konumu.

Figure 16. The dam effect due to the accumulated wastewater leakage and surface run-off behind the embankment, the seasonal changes in ground water level (case 1 and 2) and possible location of the circular slip surface.

İK-8 inklinometre kuyusunun yeraldığ 1 basamak şevinde $(137 \mathrm{~m})$ yapılan boya deneyi sonuç vermemiştir. Buna karşın, SK-4 ve İK-3 sondaj kuyuları arasındaki çukurluktan (kot: $118 \mathrm{~m}$ ) dökülen rodaminli su ofis binalarının gerisindeki dereden 27.11.2016 tarihinde çıkış yapmıştır (Şekil 16). Bu durum, heyelana ait kayma yüzeyinin katı atık şevleri içinden geçmediğine işaret etmektedir. Bir kütle içerisinde çok yumuşak bir kil bandı/tabakası 
gibi düşük makaslama dayanamına sahip eğimli, düzlemsel seviyelerin varlığg halinde, kayma düzleminin dairesel olması genellikle beklenmez. Bu tür koşullarda kaymalar, dairesel olmayan, şev tepesine yakın kesimlerde dairesel olarak başlayan ve derinde düzlemsel plastik kil tabakasını takip eden birleşik yüzey boyunca meydana gelir. İnceleme alanına yönelik olarak ikinci bir düşünce, kayma dairesi, $\mathrm{F}_{12}$ - fayının aynasını başlangıç olarak alabilir ve daha sonra yüksek plastisiteli kil bandını takip edebilir (kombine bir hareket). İnceleme alanında plastik kil bandının en kalın olduğu zon sedde altıdır. Ofis binalarına doğru ise giderek incelmektedir. Ofis binaları ve ana nakliye yolu yapay dolgu üzerinde yer almaktadır (Şekil 16). Yapay dolgu ile tabii zemin yüzeyi arasında yer alan dokanak boyunca, makaslama gerilmeleri düşüktür. $\mathrm{Bu}$ nedenle, kayma dairesi bu dokanaktan çıkarak yüzeyleyebilir. Yukarıda sıralanan etmenler ve presiyometre deney verileri dikkate alındığında, kayma dairesinin hafif iç bükey eğri bir yüzey olduğu ortaya çıkmaktadır (Şekil 16). Kayma düzleminin belirlenen konumuna göre, seddenin büyük bir bölümünün kaymayı destekleyen, göreceli daha küçük bir bölümünün de kaymayı engelleyen kayma düzlemi kesitinde yer aldığ 1 görülür. Bu durum, katı atık şevlerinde meydana gelecek olası derin bir taban heyelanında, kayarak hareket edecek sıkıştırılmış katı atıkların ana nakliye yoluna ve ofis binalarına doğru hareketini engelleyici bir işlevinin esasen olmadığını göstermektedir. Aksine, seddenin ağırlık merkezine göre büyük bir bölümü kaymayı destekler konumdadır.

18 Şubat 2013 tarihinde katı at1k düzenli depolama sahasında bir kayma hareketi başlamıştır. Hareketle beraber ana nakliye yolunda, ofis binalarında ve seddede deformasyonlar gelişmiştir. 08.03.2013'de açılan üç adet inklinometre kuyusunda yapılan okumalarda hareket eden kütlenin yanal yönde KB'ya doğru hareket miktarlarının SK-1, SK-2 ve SK-3 inklinometre kuyularında sirasıly 53 $\mathrm{mm}, 64.5 \mathrm{~mm}$ ve $35 \mathrm{~mm}$ olduğu belirlenmiştir. $\mathrm{Bu}$ veriler, başlangıç kayma hareketinden 18 gün sonra da hareketin devam ettiğini göstermektedir. Önceden hareket etmiş kütle, hareketine devam ederken sahada gözlenen deformasyonlar da ivme kazanmıştır. Ancak hareket etmiş kütle, yer değiştirmenin sonucunda, ana nakliye yoluna ve ofis binalarına doğru ilerleyerek herhangi bir yıkıma neden olmamıştır. Daha inklinometre kuyularında okumalar yapılmadan önce, öncelikli çözüme yönelik bir önlemin alınması planlanmıştır. Bu önlem; yağış ve katı atık sızıntı sularının sedde gerisinde birikmesi ve tahliye edilmesiyle kayma hareketinin hızının kesilmesi ve/veya durdurulmasi vesedde gerisinde meydana gelen baraj etkisinin ortadan kaldırılmasıdır. Böylece, sedde ile birlikte büyük bir kütlenin kayma hareketinin hızı kesilecek, belki de hareket durdurulmuş olacaktır. Bu zaman dilimi, kayma hareketinin bir heyelana dönüşmesini (progresif aşamaya geçmesini) engelleyecek, düşünülen diğer önlemlerin alınmasına da imkan sağlayacaktır. Yeraltı su seviyesinin sedde arkasından yaklaşık 50 m geriye kadar, 110-113.1 $m$ kotları arasında kalması nihai sonuç açısından dikkate alınmıştır (Şekil 16). $113.1 \mathrm{~m}$ kotu, olası kayma dairesinin yeraltında eriştiği en derin noktadır. Bu fikirler doğrultusunda, seddenin altından yatay delgi yöntemiyle boru geçirilerek sedde gerisinde biriken katı atık sızıntı suları çökeltme havuzuna aktarılmıştır. Çökeltme havuzu ile sedde altından geçirilen boru, bir kanal aracılığıyla birbirine bağlanmıştır. Yatay delgi yöntemiyle sedde altından boru geçirmek suretiyle atık su drenajının sağlanması fikrine alternatif olarak, seddede yarıklar açarak yatay delgi işlemine gerek kalmadan, drenaj borusunun doğrudan döşenmesi de düşünülmüş ancak, 
birinci çözüm önerisi uygulamaya geçirilmiştir. Önerilen çözümün etkili olduğu sonraki dönemlerde deformasyonların yavaşlamasından ve 2016 yılında gerçekleştirilen inklinometre okumalarından anlaşılmıştır.

Sedde gerisinde yer alan katı atı şevlerinde bazı hareketlenmeler, seddenin KB'ya bakan yamacında, öncekilere ek olarak gelişmiş kabarma şeklinde deformasyonlar, hareketlerin aynı kayma dairesi boyunca tekrar başladığının bir işareti olup/olmadığı kuşkusunu ortaya çıkartmıştır. 30.09.2016, 19.10.2016 ve 27.10.2016 tarihlerinde yeni inklinometre kuyularında yapılan okumalardan, kayma dairesi üzerinde herhangi bir hareket belirtisinin olmadığ1 anlaşılmıştır. İnklinometre kuyularında deformasyon ölçümleri Kasım-2016'dan sonra ilk altı ay, birer ay aralıklarla altı adet, daha sonraki zamanlarda, üç ay aralıklarla üç kez gerçekleştirilmiştir. Herhangi bir hareket belirtisinin olmamasi; kayma hareketinin yoğun yağışlarla birlikte başlamış olduğunu, bir süre devam ettiğini ve alınan basit bir önlemle (yatay delgi yöntemiyle atık su drenajı) giderek sönümlendiğini göstermektedir. $\mathrm{Bu}$ haliyle heyelanın retrogresif bir aşamaya (geriye dönük yenilme aşamasına) geçtiği anlaşılmaktadır. Diğer bir anlatımla, heyelanın retrogresif aşamadan progresif aşamaya (ileriye dönük yenilme aşaması) geçmesi, alınan basit bir önlemle bertaraf edilmiştir. Geriye dönük, işlemiş mekanizmayı anlamak ve bu mekanizmanın oluşumunda etkin parametreleri ortaya çıkarmak, çözüme giden yolu kısaltmaktadır.

İK-8 inklinometre kuyusu çok zor koşullarda, palye düzeninde yerleştirilmiş ve sıkıştırılmış katı atık şevinde açılmıştır. Yüzeyden 20.6 m sıkıştırılmış katı atık derinliği geçildikten sonra tabii zemin kotunda yer alan ayrışmış aglomeralara girilmiş ve $44.7 \mathrm{~m}$ bu birim içerisinde ilerlenmiştir. Bu kuyuda en zayıf zonun yeraldığı derinlik 40-42 m arası olarak belirlenmiştir $\left(\mathrm{P}_{\mathrm{L}}: 11.2-16.27 \mathrm{~kg} / \mathrm{cm}^{2}, \mathrm{E}_{\mathrm{M}}: 79-\right.$ $94 \mathrm{~kg} / \mathrm{cm}^{2}$ ). Sondaj profilinde katı atık seviyesi geçildikten sonra, doğal zemin seviyesinden 21.4 $\mathrm{m}$ derinde bir zayıflık zonuna (olası kayma zonu) erişilmiştir. İK-8' de yüzeyden 40-42 m, SK-4'te 20-23 m ve ofis binalarının hemen altından bir kayma dairesi geçmesi durumunda, çok büyük bir kütlenin (sıkıştırılmış katı atık+ayrışmış aglomera) hareket etmiş olması gerekirdi. Ancak Şubat-2013 kaymasında hareket eden kütle miktarı son derece sinırlıdır. Bu nedenle, 2013 Şubat ve Nisan aylarında oluşan kayma hareketiyle ilgili, seddenin çok gerisinden başlayan, seddeyi de içine alan olası bir kayma dairesi hipotezi, veriler 1şığında muhtemel görünmemektedir. Ancak önceden hareket etmiş bu kütle yeni bir dış etmenle (yoğun yağış, katı atık şevlerinin şev yüksekliklerinin artması, sismik aktivite vb.) tekrar harekete geçebilme potansiyeline sahiptir. Kayma hareketi sonucunda yenilmiş kütleler rezidüel dayanım parametrelerine $\left(\mathrm{c}_{\mathrm{r}}, \varphi_{\mathrm{r}}\right)$ sahip olurlar. Bu nedenle, kritik denge halindedirler. Kayma hareketinin başlaması, bir süreliğine devam etmesi ve daha sonra hareketin yavaşlayarak durması (kritik dengede stabil bir durum seyretmesi) heyelanın retrogresif bir aşamaya geçtiğine, geçici bir stabiliteye erişmiş olduğuna işaret etmektedir. Söz konusu hareketin progresif bir aşamaya geçmesi bir dış etmenin beklenmedik müdahalesiyle mümkündür. Stabilite analizlerinin sonucunda, sedde önüne, uygun düzende, uygun derinliğe (kayma dairesi altına) soketlenecek beton kazık uygulaması problemin kalıcı çözümüne yönelik radikal bir önlem olacaktır. 
Kıncal, Kadakci Koca, Koca

\section{KAYNAKLAR}

Akbaş, B., Akdeniz, N., Aksay, A., Altun, İ.E., Balc1, V., Bilginer, E., Bilgiç, T., Duru, M., Ercan, T., Gedik, İ., Günay, Y., Güven, İ.H., Hakyemez, H.Y., Konak, N., Papak, İ., Pehlivan, Ş., Sevin, M., Şenel, M., Tarhan, N., Turhan, N., Türkecan, A., Ulu, Ü., Uğuz, M.F., Yurtsever, A. 2011. 1:1.250.000 ölçekli Türkiye Jeoloji Haritası. Maden Tetkik ve Arama Genel Müdürlüğü Yayını, Ankara-Türkiye.

ASTM D2435 - 04, 2013. Standard Test Method for One - Dimensional Consolidation Properties of Soils Using Incremental Loading. West Conshohocken, PA.

ASTM D3080-04, 2004. Standard Test Method for Direct Shear Test of Soils Under Consolidated Drained Conditions, West Conshohocken, PA.

ASTM D4318 -10e1, 2010. Standard Test Method for Liquid Limit, Plastic Limit, and Plasticity Index of Soils. West Conshohocken, PA.

ASTM D4719 - 00, 2000. Standard Test Method for Prebored Pressuremeter Testing in Soils. West Conshohocken, PA.

ASTM D6230 - 13, 2013. Standard Test Methos for Monitoring Ground Movement Using Probe Type Inclinometers. West Conshohocken, PA.

DEÜ, 2016. İzmir Büyükşsehir Belediyesi Harmandalı düzenli katı atık depolama sahası sedde önü şev stabilite problemleri ve çöp yığınlarının stabilitesi için değerlendirme ve stabilite önlemleri projesi raporu, Jeoloji Müh. Bölümü, İzmir, $98 \mathrm{~s}$ (yayımlanmamış).
Erdoğan, B., 1990. İzmir-Ankara Zonu'nun İzmir ile Seferihisar arasındaki bölgede stratigrafik özellikleri ve tektonik evrimi. TPJP Bülteni, 2(1), 1-20.

Günay, G., Erkan, Y., Kocaefe, S., Yeşertener, C., Çağlan, D., Ekmekçi, M., Erduran, B., Akkuş, N., Varol, Z., 1990. İzmir-Harmandalı Çöp Depolama Alanı Zemin Araştırmaları Raporu. Hacettepe Üniversitesi Uluslararas1 Karst $\mathrm{Su}$ Kaynakları Uygulama ve Araştırma Merkezi, Ankara, $40 \mathrm{~s}$ (yayımlanmamış).

Holtz, R.D., Kovacs, D., 1981. An Intruduction to Geotechnical Engineering, Prentice Hall Inc., New Jersey, 736 p.

Kıncal, C., Kadakçı Koca, T., Koca, M.Y., 2017. Jeolojik bariyer olarak faylar, örnek çalışma: Çiğli Evka-5 heyelanı (İzmir). Jeoloji Mühendisliği Dergisi, 41, 1-30.

Koca, M. Y., 1999. İzmir yöresinde andezitlerin bozunma ürünü killerin oluşum şekilleri ve mühendislik özellikleri. Türkiye Jeoloji Bülteni, 42 (2), 39-49.

Koca, M.Y., Türk, N., 1994. Ayrışmanın andezitlerin petrografik, kimyasal ve jeomekanik etkisi. Türkiye Jeoloji Kurultay1, TMMOB Jeoloji Mühendisleri Odas1, Ankara, 373-382.

Mikkelsen, P. E., 1996. Field instrumentation. Landslides: Investigation and Mitigation, Special Report (Editors: A. K. Turner and L. Schuster), Transportation Research Board, National Research Council, Washington, D. C., 278-318. 